\title{
Hvernig opinber stefna gerist: Stefnurek í málefnum lesblindra á Íslandi 1990-2007
}

\author{
Nanna Björk Bjarnadóttir, félagsráđgjafi, MPA, Sigurbjörg Sigurgeirsdóttir, \\ lektor í opinberri stjórnsýslu við Stjórnmálafræđideild Háskóla Íslands
}

\section{Útdráttur}

pessi grein fjallar um opinbera stefnumótun í málefnum nemenda með lesblindu á Íslandi. Talið er að stærsti hópur nemenda með námserfiðleika innan skólakerfisins séu nemendur með lesblindu. Til að átta sig á núverandi stöðu í pessum málaflokki, er stefnuferlið í málefnum nemenda á grunn- og framhaldskólastigi á Íslandi rakið yfir tímabilið 1990-2007. Gerður er samanburður á helstu einkennum pessarar stefnumótunar og peirri stefnumótun sem átti sér stað í aðdraganda að sameiningu sjúkrahúsanna í Reykjavík á tíunda áratugnum. Markmiðið er að auka skilning á pví hvernig opinber stefnumótun gengur almennt fyrir sig og hvernig slíkur skilningur getur varpað ljósi á áhrif stefnunnar. Jafnframt er hugmyndin að koma fram með nýtt sjónarhorn inn í umræðuna um stefnumótun stjórnvalda í málefnum lesblindra. Niðurstöður rannsóknarinnar gefa til kynna að niðurstaða stefnumótunar í málefnum lesblindra, líkt og með sameiningu sjúkrahúsanna í Reykjavík, sé afleiðing ferlis sem einkennist af stefnureki í stað yfirlýstrar stefnumörkunar. Ástæðuna má rekja til ríkjandi stefnu stjórnvalda um valddreifingu á tíunda áratugnum, sem leiddi til enn frekari sundrungar innan sérfræðingasamfélagsins og ýtti undir markaðsvæðingu á sérfræðipjónustu fyrir nemendur með lesblindu. Par sem sérstök áhersla var lögð á að valddreifa myndaðist ekki sameiginlegur skilningur innan málaflokksins og par af leiðandi byggðist ekki upp svokallaður „krítískur massi“ af peirri reynslu og sérfræðipekkingu sem parf að vera fyrir hendi til pess að vísindalegar rannsóknir og próun geti með áhrifaríkum hætti mótað gagnreynda pekkingu sem undirstöðu stefnumarkandi ákvarðana í málefnum lesblindra.

Efnisorð: Lesblinda, opinber stefnumótun, hagsmunahópar, fagskrifræði.

\author{
Icelandic Review of Politics and Administration Vol. 9, Issue 1 (53-77) \\ (c) 2013 Contact: Nanna Bjarnadóttir, nannabjarnad@gmail.com \\ Article first published online June 26th 2013 on http://www.irpa.is \\ Publisher: Institute of Public Administration and Politics, Gimli, Sæmundargötu 1, 101 Reykjavík, Iceland \\ Stjórnmál \& stjórnsýsla 1. tbl. 9. árg. 2013 (53-77) Fræđigreinar \\ (c) 2013 Tengiliður: Nanna Bjarnadóttir, nannabjarnad@gmail.com \\ Vefbirting 26. júní 2013 - Birtist á vefnum http://www.stjornmalogstjornsysla.is \\ Útgefandi: Stofnun stjórnsýslufræđa og stjórnmála, Gimli, Sæmundargötu 1, 101 Reykjavík \\ DOI: http://dx.doi.org/10.13177/irpa.a.2013.9.1.3 \\ This work is licensed under a Creative Commons Attribution 3.0 License.
}


STJÓRNSÝSLA

\title{
How public policies happen: Policy drift shapes policies for people with dyslexia in Iceland
}

\begin{abstract}
This study is about public policy-making for people with dyslexia in Iceland. Pupils with dyslexia are as a group the biggest group inside the educational system dealing with learning difficulties at school. In order to make sense of the current situation in this policy sector, the paper traces the processes by which policies for pupils with dyslexia at primary and secondary school levels in Iceland are made in the period 1990-2007. It identifies similarities and differences in the policy-making processes and compares the results with similarities and differences characterising the policy-making processes involved in merging the hospitals in Reykjavik in the 1990s. The aim is to bring out a better understanding about how public policies come about in general, but more specifically to bring new perspectives into the policy debate, in the hope it may encourage a new way of thinking about the ways policies for people with dyslexia are designed. The paper concludes that similar to the hospital reforms at the end of 1990s, the observed policy outcomes of educational policies for pupils with dyslexia in Iceland are a result of processes characterised by policy drift rather than stated public policy reforms. As a consequence, the growing fragmentation of the policy sector following the decentralisation in the 1990s, lack of coherent and cohesive community of professional expertise, and marketization of specialised services for pupils with dyslexia impede the formation of collective understanding inside the sector and the building up of a critical mass of experience and expertise in order to advance the scientific research and development necessary to effectively develop and design evidence-based policy responses to pupils with learning difficulties caused by dyslexia.
\end{abstract}

Keywords: Dyslexia, public policy making, interest groups, professionalbureaucracy.

\section{Inngangur}

pessi grein fjallar um stefnumótun í málefnum nemenda með lesblindu í grunnskólum landsins. Umfjöllunin byggir á niðurstöðum meistaraprófsrannsóknar í opinberri stjórnsýslu við Stjórnmálafræðideild Háskóla Íslands sem var unnin á árunum 2011-2012. ${ }^{1}$ Tilgangur rannsóknarinnar var tvípættur. Annars vegar að öðlast frekari skilning og pekkingu á stefnumótun hins opinbera á Íslandi almennt og hins vegar að varpa nýju ljósi á stöðu nemenda með lesblindu innan skólakerfisins. Greinin er byggð á pessari rannsókn en tilgangurinn hér er að skoða pessa tilteknu stefnumótun í víðara samhengi. Баð er gert til að auka skilning á opinberri stefnumótun á Íslandi almennt og skoða pennan málaflokk sérstaklega út frá nýju sjónarhorni ef pað mætti verða til pess að ræða gamlar og nýjar spurningar í nýju ljósi og par með örva almenna umræðu um málefni nemenda með lesblindu á Íslandi. Skoðuð er stefnumótun í pessum tiltekna málaflokki á ákveðnu 
tímabili í peim tilgangi að greina hvaða öfl; pólitísk, fagleg og fagpólitísk liggi par að baki og hvaða áhrif samspil peirra hafi á framkvæmd og niðurstöðu stefnunnar í grunnskólum landsins.

Pessi stefnumótun í málefnum lesblindra ${ }^{2}$ á Íslandi og helstu einkenni, sem par koma fram, er síðan borin saman við stefnumótun í heilbrigðismálum á tíunda áratugnum. Par er byggt á rannsókn Sigurbjargar Sigurgeirsdóttur á sameiningu sjúkrahúsanna í Reykjavík. ${ }^{3}$ Með pví að draga fram og skoða helstu einkennin á stefnumótuninni í pessum tilteknu málum innan stærstu málaflokka hins opinbera á Íslandi, má fá betri skilning á pví hvernig samspilið milli stjórnmála og stjórnsýslu virkar almennt, og hvað sérstaklega styður eða kemur í veg fyrir að tilætlaður árangur af stefnumörkun stjórnvalda nái fram að ganga. Með slíkum samanburði má varpa ljósi á pað hvernig opinber stefnumótun gengur almennt fyrir sig á Íslandi.

prátt fyrir að yfirvöld hafi beitt sér fyrir ýmsum úrbótum í málefnum lesblindra á undanförnum árum eru vísbendingar um að enn vanti talsvert á innan skólakerfisins til pess að pjónustan við pessa nemendur geti talist góð eða fullnægjandi. Einkum hefur verið bent á að pekkingu á lesblindu, einkennum hennar og leiðum til að mæta pörfum lesblindra skorti innan grunnskólanna og að afstaða peirra gagnvart málaflokknum sé bæði óljós og sundurleit. Sú staðreynd að margir foreldrar lesblindra nemenda leita eftir úrræðum utan skólakerfisins vekur upp pá spurningu hvernig pað samrýmist stefnumörkun stjórnvalda almennt í málefnum grunnskólans og í málefnum pessa nemendahóps sérstaklega. ${ }^{4}$

Nemendur með lesblindu eru taldir vera stærsti hópur peirra sem glíma við námserfiðleika innan skólakerfisins. ${ }^{5}$ Pessir nemendur eru í áhættuhópi. Peir gefast oft upp á náminu og flosna snemma upp úr skóla. Í kjölfarið margfaldast aðrir áhættupættir sem geta ýtt undir pað að pessir einstaklingar eigi erfitt með að fóta sig í samfélaginu. Brottfall úr námi er ekki eingöngu dýrkeypt fyrir einstaklinginn heldur allt samfélagið. Prátt fyrir erfiðleika eiga nemendur með lesblindu að geta náð árangri í skóla ef peir fá viðeigandi greiningu, stuðning og tileinka sér rétt vinnubrögð. Bent hefur verið á mikilvægi „,snemmtækrar íhlutunar“, 6 p.e. að vandinn sé greindur sem fyrst par sem áframhaldandi skólaganga barns getur ráðist af pví hvernig til tekst í byrjun. Af pessum ástæðum er ljóst að sú ráogjöf og pjónusta sem grunnskólar veita á fyrstu árum skólagöngunnar skiptir ekki aðeins sköpum fyrir pennan nemendahóp, heldur skiptir pað máli fyrir samfélagið allt hvort og jafnframt með hvaða hætti tekið er á málefnum pessara nemenda.

Greinin skiptist í fjóra meginkafla. Í fyrsta kafla verður gerð grein fyrir peim kenningum sem stuðst er við pegar gögnin eru skoðuð og útskýrð. Pessar kenningar eru byggðar á rannsóknum par sem athyglinni er beint að stefnumótandi breytingum í pólitísku samhengi. Leitað er svara við spurningum höfunda í stefnumótunarferlinu sjálfu og stuðst við kenningar sem kallast einu nafni „dagskrárkenningar“ pví að par er leitast við að útskýra hvernig og hvers vegna tiltekin mál komast á dagskrá stjórnmálanna. Pessar kenningar leitast einnig við að skýra hvers vegna afskipti stjórnvalda leiða stundum til breytinga, sem samræmast markmiðum stjórnvalda, en stundum ekki. Í öðrum kafla verður gerð grein fyrir núverandi stöðu í málefnum lesblindra á Íslandi. Sú próun, sem 


\section{STJÓRNSÝSLA}

varð til pess að málefni nemenda með lesblindu komst á dagskrá stjórnmálanna, og enn fremur hvernig pessi málaflokkur próaðist í kjölfarið, er viðfangsefni í priðja kafla. Að lokum verður fjallað um helstu einkenni, sem greina má í stefnumótun málaflokksins, og pessi einkenni skoðuð með samanburði við stefnumótun stjórnvalda í aðdraganda að sameiningu sjúkrahúsanna í Reykjavík.

\section{Kenningar innan stjórnsýslufræđanna}

Hér er gerður greinarmunur á stefnumörkun annars vegar og stefnumótun hins vegar. Með stefnumörkun stjórnvalda er tekin ákvörðun um pau markmið sem tiltekin stefna á að ná fram. Slíkar ákvarðanir eru á valdi Alpingis með lagasetningu eða pingsályktunum, með ákvörðunum ríkisstjórna eða á hendi ráðherra með reglugerðum eða öðrum fyrirmælum um áherslur og forgang. Stefnumótun er aftur á móti ferli sem á sér stað bæði sem undirbúningur í aðdraganda stefnumarkandi ákvörðunar stjórnvalda og í kjölfar slíkrar ákvörðunar. Stefnumótun, sem tekur við í kjölfar stefnumörkunar, er í höndum framkvæmdaaðila, sem í umboði ráðherra finna stefnunni pann farveg sem er talinn pjóna peim markmiðum sem að er stefnt. Pegar pessu ferli lýkur blasir stundum við önnur niðurstaða en að var stefnt eða að tilætlaður árangur hefur ekki náðst. Skýringuna má oftast finna í peim hluta stefnumótunarinnar sem á sér stað í kjölfar stefnumörkunar eftir að málin eru komin úr höndum Alpingis, ríkisstjórnar eða ráðherra (Sigurbjörg Sigurgeirsdóttir, 2006b, 2006c).

Stefnumörkun stjórnvalda er sjaldnast pannig úr garði gerð að par hafi verið tekið á öllum atriðum sem upp kunna að koma við framkvæmd opinberrar stefnu. Stefnumörkunin felur fyrst og fremst í sér að skilgreina markmiðin, hverjum sé falin ábyrgð á framkvæmdinni og hverju skuli til kostað til pess að ná markmiðunum. Đað hvernig nákvæmlega er staðið að framkvæmdinni að öðru leyti er gjarnan látið í hendur peirra sem best pekkja til. En fulltrúar peirra sem best pekkja til koma oftast einnig að stefnumótuninni við undirbúning ákvörðunar, p.e. áður en stefnan er mörkuð.

Hill (2009) hefur bent á að náið samráð af pessu tagi við stefnumótun hins opinbera sé óhjákvæmilegt, m.a. vegna pess að peir aðilar, sem eiga að sjá um innleiðinguna á stefnunni, eru einnig peir sem hafa pekkingu og aðstöðu til að hafa áhrif á árangur hennar. Ef peir eru ekki hafðir með í ráðum eru minni líkur á pví að markmið stjórnvalda nái fram að ganga. Af pessu má sjá að pað að koma tilteknu máli að á dagskrá stjórnmálanna í peim tilgangi að ná fram breytingum og pað að fylgja pví máli eftir í framkvæmd, er ekki aðeins nátengt peim aðilum sem eiga hagsmuna að gæta í niðurstöðunni, heldur einnig peim sem með einum eða öðrum hætti eiga hagsmuna að gæta við framkvæmdina.

Margir gera ráo fyrir pví að opinber stefnumótun snúist um val milli nokkurra vel ígrundaðra lausna og að yfirleitt sé á endanum tekin ákvörðun um skynsamlegustu leiðina. Pegar sú ákvörðun liggur fyrir tekur við tiltölulega fyrirsjáanlegt ferli innleiðingar og framkvæmdar. Peir sem hefja störf innan opinberrar stjórnsýslu verða pess fljótt áskynja að málið er ekki alveg svona einfalt. Hér takast gjarnan á ólík sjónarmið stjórnmálanna annars vegar, og hins vegar afar ólíkir hagsmunir peirra aðila sem eiga hagsmuna að gæta 1 framkvæmd og niðurstöðu stefnunnar (Sigurbjörg Sigurgeirsdóttir, 2006c). Deir 


\section{STJÓRNMÁL \& \\ STJÓRNSÝSLA}

Herbert Simon (1947) og Charles E. Lindblom (1959) tókust á um petta atriði í líflegri umræðu á sjötta og sjöunda áratug síðustu aldar. Á meðan Herbert Simon var að lýsa pví hvernig stefnumótun ætti að vera, pá var Charles E. Lindblom að lýsa raunveruleikanum. Eftir pví sem á leið í pessari umræðu skýrðust pær hugmyndir Charles E. Lindbloms (1979) sem birtust síðan í smáskrefakenningunni.

Bandaríski stjórnmálafræðingurinn, John W. Kindgon (2003), er pekktur fyrir dagskrárkenningu sína um glugga takifaranna. Hann gengur út frá hugmyndum Charles E. Lindblom um að breytingar hjá hinu opinbera gerist í smáum skrefum, en sýnir aftur á móti fram á að stundum bregði út af og að meiriháttar breytingar á stefnu stjórnvalda eigi sér stað. Hann byggir kenningu sína á áralöngum rannsóknum á stefnubreytandi ákvörðunum í heilbrigðismálum og samgöngumálum innan bandarísku stjórnsýslunnar. Kingdon kortleggur og lýsir pví hvernig hugmyndir próast í meðförum annars vegar sérfræðinga og hins vegar stjórnmálamanna, og með hvaða hætti hugmyndir próast innan kerfisins og fá eða fá ekki hljómgrunn. Rannsóknir hans hafa sýnt að til að meiriháttar breytingar verði purfi prennt að koma til: Í fyrsta lagi verða menn að standa andspænis vandamáli sem allir eru sammála um að hið opinbera purfi að leysa með einum eða öðrum hætti. Í öðru lagi purfi menn að hafa komið sér saman um ákveðna lausn á vandamálinu. Og í priðja lagi purfa að vera til staðar ákveðnar pólitískar aðstæður, t.d. stjórnarskipti eða ráðherraskipti sem skapi ný tækifæri til aðgerða í málinu.

Deir sem próa lausnirnar með rannsóknum og pekkingu eru sérfræðingar hver á sínu sviði. Hann vísar til pessa hóps sem stefnusamfélags (e. policy community). Kingdon bendir á að pegar samstaða (e. cohesion) ${ }^{7}$ ríkir um stefnur og strauma meðal sérfræðinga innan stefnusamfélagsins ríki ákveðinn stöðugleiki í viðkomandi málaflokki. Đað pýðir í raun að litlar sem engar breytingar verða á skipulagi starfseminnar. Aftur á móti ef sérfræðingar innan stefnusamfélagsins, sem við skulum hér eftir kalla sérfræðingasamfélag, eru ekki á einu máli, p.e. stefna pekkingarinnar er mjög sundurleit og ómarkviss, pá leiði pað til pess að stefna hins opinbera verður pað einnig. Sams konar áhrif samstöðu eða samstöðuleysis er víða að finna í rannsóknum á opinberri stefnumótun innan stjórnsýslu og stjórnmálafræðanna (Birkland, 2005; Howlett og Ramesh, 2003; Kavanagh, Richard, Smith og Geddes, 2006; Rhodes, 1999).

Í stuttu máli eru pessar rannsóknir á eiginleikum sérfræðingasamfélagsins að segja pað að pegar samstaða sérfræðinga sé mikil sé erfiðara fyrir stjórnvöld að eiga frumkvæði að stefnubreytingum og ná peim fram. Öðru máli gegnir pegar frumkvæði að breytingum kemur frá sérfræðingasamfélaginu sjálfu par sem samstaða er mikil. Aftur á móti, ef samstaða er lítil vegna pess að sjónarmið sérfræðinga eru mismunandi eða hagsmunir sundurleitir, eiga stjórnvöld hægara um vik að koma fram sínum stefnubreytingum.

Kingdon (2003) gerir í umfjöllun sinni grein fyrir áhrifum ósamstöðu innan sérfræðingasamfélagsins á stefnumótun hina opinbera. Рað kemur hins vegar ekki fram í rannsóknum Kingdons hvað veldur ósamstöðunni innan sérfræðingasamfélagsins og hvernig pað gerist. Раð kemur aftur á móti fram í rannsóknum kanadíska stjórnmálafræðingsins Carolyn Tuohy (1999). Hún setur hugmyndir Kingdons í víðara pólitískt samhengi. Með rannsóknum sínum veitir hún innsýn í gangverk eða virkni (e. dynamics) stefnubreytinga 


\section{STJÓRNSÝSLA}

á sviði heilbrigðismála í Bandaríkjunum, Kanada og Bretlandi. Par skilgreinir hún og parar saman skipulagsform (e. structures) og ákvarðanatökukerfi (e. institutions).

Tuohy sér fyrir sér prjú ráðandi skipulagsform innan heilbrigðiskerfa sem hvert um sig ber með sér sitt ákvarðanatökukerfi. Petta eru ríkið sem byggir ákvarðanir á stigveldi (e. hierarchy), laknastéttin sem byggir ákvarðanir á stéttarfélagslegri samstöðu (e. collegiality) og einkafjármagn (hvort heldur sem er í formi einkagreiðslna fyrir pjónustu eða fjárfestingar í einkarekstri) par sem ákvarðanir gerast á markaði (e. markets). Að mati Tuohy hafa hvert pessara kerfa einkennandi innri „dýnamik“. Раð sem einkennir stigveldið er seinagangur (e. delay) sem hefur tilhneigingu til að draga úr pólitískum stuðningi, líkt og rannsókn peirra Pressman og Wildavsky (1973) sýndi á sínum tíma. Hægar smáskrefabreytingar einkenna hins vegar kerfi stéttarfélagslegrar samstöðu (e. incremental consensually driven change) par sem jafningjar innan stéttarfélags leitast við að mynda samstöðu um breytingar. Breytingar á markaði einkennast aftur á móti af óskipulögðum og sviptingasömum (e. turbulent) breytingum. Pessi kerfi geta pannig bæði auðveldað og hindrað stefnubreytingar stjórnvalda eða áhrif peirra.

Tuohy lítur svo á að einstaklingar almennt hugsi um eigin hagsmuni hvort heldur peir eru fjárhagslegir, faglegir eða af öðru tagi. Hún komst að pví eins og fleiri (Barrett og Fudge 1981) að almennt sé mjög erfitt að ná fram breytingum að frumkvæði stjórnvalda innan opinberra kerfa. Breytingar verða einna helst við pað að jafnvægi valds og áhrifa milli pessara skipulagsforma innan kerfanna raskast. Баð sem parf til að svo verði að mati Tuohy er sampjöppun á pólitísku valdi (e. consolidated political authority), hér kallað pólitískur einhugur sem varir lengi og skýrar stefnumótandi áherslur sem njóta afgerandi forgangs og pólitískrar forystu. Touhy segir að nauðsynlegt sé að pessar aðstæður séu til staðar en pó sé pað ekki nægilegt til að ná fram meiriháttar breytingum. Árangur af tilraunum stjórnvalda til að koma á breytingum ræðst að hennar mati af pví hvers konar hugmyndir og lausnir sérfræðingasamfélagið býður upp á pá stundina pegar hinum pólitísku skilyrðum er náð og hvaða hugmyndir pað séu sem best falla að meginsáherslum og hugmyndum stjórnvalda. Раð að petta allt fari saman, segir Tuohy, að sé sjaldgæft. Petta stefnumót milli stjórnvalda og viðtekinna hugmynda innan málaflokksins, sem Touhy kallar „goodness-of-fit“, mótar síðan farveg próunarinnar innan málaflokksins eða takmarkar svigrúm til breytinga í framhaldi af inngripi stjórnvalda 1 starfsemi málaflokksins við pessar tilteknu aðstæður.

Í stuttu máli pá geta stjórnvöld náð árangri með inngripum í málefni með pví að höfða til afmarkaðs hóps innan sérfræðingasamfélagsins, hóps sem gerir stjórnvöldum kleift að koma fram stefnu sem fellur að peirra pólitísku sjónarmiðum. Stjórnvöld geta m.ö.o. hundsað heildarsamtök sem ekki geta talað einum rómi út á við. Dví má segja að pegar samtök sérfræðinga geta ekki lengur talað einum rómi skapist ákveðin tækifæri fyrir stjórnvöld að koma sínum áherslum að.

Рað er pessi sýn á eðli og eiginleika sérfræðingasamfélagsins, hið pólitíska samhengi stefnumótunarinnar og áhrif pessa á stefnubreytingar sem gerir rannsóknir Kingdons og Tuohy að áhugaverðum kenningum sem varpað geta ljósi á opinbera stefnumótun á 
Íslandi. En pá má spyrja hvernig til dæmis kennarar sem fagstétt eða sérfræðingahópur fellur að pessum skilgreiningum Kingdons og Tuohy um sérfræðingasamfélag.

Í rannsókn sinni á stefnumótun í málefnum lesblindra á Íslandi skoðaði Nanna Björk einmitt kennarastéttina í ljósi kenninga Henry Mintzbergs (1993) um skipulagsheildir. Dar tekur Mintzsberg skóla sem dæmi um skipulagsheildir sem einkennast af svokölluðu fagskrifradi (e. professional bureaucracy). Fagskrifræði einkennist af valddreifingu sem kemur fram í miklu sjálfdami (e. autonomy) sem fagaðilar hafa í eigin starfi, sem fram fer í nánum tengslum við skjólstæðinginn. Pjónustan, sem fagaðilar veita, er pess eðlis að hún gerir ráð fyrir pví að meta purfi ákveðnar parfir og mæta peim með tilteknum hætti. Hvorttveggja gerir kröfur til ákveðinnar pekkingar sem verður hvorki stýrt né framkvæmd samkvæmt fyrirmælum stjórnenda. Forsendan fyrir pví að hægt sé að ná fram skilvirku skipulagi innan slíks fagskrifræðis er að koma á samhæfingu aðgerða í formi staðlaðrar pekkingar og verkkunnáttu. Í fagskrifræði er staðlaðri pekkingu fyrst og fremst komið á með pjálfun og innrætingu í gegnum háskólanám, starfspjálfun og pátttöku í stéttarfélagi.

Degar fagskipulag einkennist af valddreifingu er pörf fyrir samstarf pvert á kerfið til pess að koma á samræmdum breytingum sem hafa ekki verið innrættar með náminu sjálfu. Að mati Mintzbergs getur verið erfitt að koma á slíku samstarfi meðal fagaðila par sem pað fer gegn sjálfdæmi peirra í starfi. Đað lýsir sér í pví að peir vilja ákveða, eða stjórna pví sjálfir, hverju skuli breytt og hvernig. Deir hafi pví tilhneigingu til pess að sporna gegn kerfisbundnum breytingum sem miða að samræmingu. Til að tryggja pað hins vegar að stefna stjórnvalda nái fram að ganga við slíkar aðstæður leitast stjórnvöld við að efla ytra aðhald og eftirlit til dæmis með aukinni beinni umsjón eða með pví setja á laggirnar einhvers konar eftirlitskerfi (Mintzberg, 1993).

\subsection{Opinber stefnumótun á Íslandi}

Stefnumótun á Íslandi hefur verið lýst sem nánu samráði par sem stjórnvöld í raun láti hagsmunaaðilum eftir að móta og framkvæma stefnuna. Með tilliti til tengslanna milli stjórnvalda og einstakra greina atvinnulífsins pá séu stjórnvöld í tiltölulega veikri stöðu sem helgist af pví að hagsmunaaðilar séu peir sem hafi pá pekkingu og aðstöðu sem til parf til að stefna nái fram að ganga. Baldur Pórhallson (2010) bendir t.d. á að íslensk stefnumótun hafi lengst af einkennst af miklu samráði par sem stjórnvöld hafa í raun allt fram á pessa öld látið hagsmunaaðila að miklu leyti um að marka og framkvæma stefnu hins opinbera í tengslum við fiskveiðistjórnun, landbúnað og áliðju.

Detta má sjá bæði í rannsóknum Halldórs Jónssonar (1990) og Svans Kristjánssonar (2011) á stefnumótun varðandi tilkomu kvótakerfisins í sjávarútvegi. Sú stefna virðist hafa mótast fyrst og fremst af hagsmunaaðilum sem beittu miklum prýstingi í kjölfar aflasamdráttar sem átti sér stað árið 1983, p.e. í aðdraganda ákvörðunarinnar sem tekin var pá um kvótakerfið. Enn fremur hafa rannsóknir Gunnars Helga Kristinssonar og félaga (1992) sýnt að í raun gildir pað sama fyrir stefnumótun í landbúnaði og sjávarútvegi. Stjórnvöld reiði sig nánast alfarið á pekkingu sem er að finna innan raða hagsmunaaðila 
í pessum frumatvinnugreinum hagkerfisins. Að mati Ríkisendurskoðunar (2011) pykir petta samráð nú í raun of náið.

Af pessu má ráða að geta og hæfni íslenskrar stjórnsýslu til að undirbúa og fylgja eftir stefnumörkun stjórnvalda markist nokkuð af pessari hefð. En pessar rannsóknir hafa beinst að tekjuskapandi greinum hagkerfisins. Á útgjaldahlið hagkerfisins er aftur að finna opinbera pjónustu á borð við heilbrigðis- og menntamál par sem hið opinbera er ráðandi aðili, bæði sem eigandi aðstöðunnar og sem kaupandi pjónustunnar. Hvernig skyldi pessu samráði vera háttað milli stjórnvalda og hagsmunaaðila innan pessara greina hagkerfisins?

Rannsókn Sigurbjargar Sigurgeirsdóttur (2006a) á sameiningu sjúkrahúsa í Reykjavík og í London fjallar um tilraunir stjórnvalda til að koma á stefnumarkandi breytingum innan heilbrigðiskerfanna í Bretlandi og á Íslandi. Par var leitað svara við peirri spurningu hvað skýrði pað að hægt var að sameina háskólasjúkrahús í pessum borgum á pessum tíma prátt fyrir áratuga andstöðu fagstétta innan kerfanna. Niðurstöður hennar sýndu að sameining sjúkrahúsanna í Reykjavík, sem var stefnumörkun stjórnvalda, p.e. ríkisins, náðist fram, annars vegar vegna afgerandi forgangsröðunar sem naut pólitískrar forystu, stöðugleika og samstöðu, og hins vegar vegna pess að samstöðu skorti meðal sérfræðinga sem voru ráðandi innan sérfræðingasamfélagsins í íslenska heilbrigðiskerfinu. раð vekur athygli að í pessu máli ráku stjórnvöld stefnu sem fól í sér mótsagnakennd sjónarmið, en sem fyrir vikið náði að höfða með mismunandi hætti til ólíkra hópa á ólíkum stigum málsins. Í fyrsta lagi átti sameining sjúkrahúsanna að leiða til hagræðingar og lækkunar útgjalda sjúkrahúsanna í Reykjavík. Pessi sjónarmið féllu að sjónarmiðum heilbrigðispjónustunnar á landsbyggðinni. Í öðru lagi var sjónarmiðið um mikilvægi sérhæfingarinnar, sem fól í sér myndun á svokölluðum „krítískum massa“ sjúklinga og starfsfólks í págu aukinnar sérhæfingar, sem tryggja átti gæði og öryggi pjónustunnar. Pessi rök féllu vel í kramið hjá heilbrigðisstéttum innan háskólasamfélagsins og studdu par með rökin um sameiningu sjúkrahúsanna. Í priðja lagi var um að ræða sjónarmiðið um rétt sjúklinga til að velja sér sinn eigin lækni, sem féll vel að sjónamiðum sérgreinalækna sem vildu stunda lækningar og fá greitt fyrir hvert verk samkvæmt samningi við Tryggingastofnun ríkisins. Pessi sjónarmið leiddu til vaxandi starfsemi sérgreinalækna á einkastofum peirra út í bæ, nokkuð sem Sigurbjörg hefur vísað til sem stefnureks (Sigurbjörg Sigurgeirsdóttir, 2006a, 2006c).

Stefnurek felur í sér grundvallarbreytingar á kerfum án pess að yfirlýst stefnumörkun stjórnvalda hafi komið til (Hacker 2002). Stefnurek á sér stað pegar stefnumótandi ákvarðanavald er óljóst eða eftirfylgni stjórnvalda með stefnumörkuninni er lítil. Баð leiðir til pess að peir sem eiga hagsmuna að gæta í framkvæmd stefnunnar ná yfirhöndinni og ná að móta framkvæmd stefnunnar meira út frá eigin hagsmunum en út frá markmiðum stjórnvalda. Hagsmunir framkvæmdaaðila fara ekki alltaf saman með stefnumörkun stjórnvalda. Pegar peir aðilar, sem fara með framkvæmd stefnumótunar, nýta pað svigrúm, sem skapast með lítilli eða óskýrri eftirfylgni, til að sveigja stefnumótunina sér í hag getur stefnumótunin vikið frá markmiðum stjórnvalda og leitt til annarrar niðurstöðu en ráð var fyrir gert. Đá á sér stað stefnurek. Drifkraftar í slíku stefnureki eru 
einkahagsmunir. Stefnurek getur leitt til pess að reynsla innan kerfisins verður dreifð og pekking brotakennd. Par með er grafið undan pekkingarpróun sem sækir efnivið í sameiginlegan reynslubrunn. Stefnurek getur líka leitt til ójöfnuðar meðal notenda í peim tilvikum par sem stefnurek leiðir til pess að lögmál markaðarins verða ráðandi. Í peim tilvikum par sem talið er að hagkvæmni, gæðum og öryggi opinberrar pjónustu sé betur borgið með pví að markaðsvæða pjónustuna, purfa stjórnvöld að hafa nægilegt eftirlit með framkvæmdinni til að tryggja að slík markmið náist. Рað parf öfluga og samhenta opinbera stórnsýslu til að ná markmiðum hins opinbera með einkavæðingu opinberrar pjónustu (Kettle, 1993).

Í greiningu Héðins Unnsteinssonar og Péturs Berg Matthíassonar (2012) á stefnum og áætlunum innan íslenskra ráðuneyta kom fram að prátt fyrir góðan undirbúning við stefnugerð, einkum varðandi greiningu og setningu markmiða, eru stefnur og áætlanir sjaldan fjármagnstengdar, framkvæmdin er oft á tíðum ófullnægjandi og ómarkviss, og eftirfylgni virðist vera mjög takmörkuð. Svo virðist sem ráðuneytin móti ekki stefnu með markvissum hætti og pví endurspegli stefnan fremur fögur fyrirheit en raunverulegar aðgerðir.

\section{Núverandi stađa í málefnum lesblindra grunnskólabarna}

Samkvæmt núgildandi grunnskólalögum nr. 91/2008 eru öll börn á aldrinum 6 til 16 ára skólaskyld og eiga pau rétt á kennslu við hæfi sem tekur mið af pörfum peirra og almennri vellíðan. Í 1. og 2. mgr. 17. gr. laganna er fjallað sérstaklega um nemendur með sérparfir en par kemur fram að:

„Nemendur eiga rétt á að komið sé til móts við námsparfir peirra í almennum grunnskóla án aðgreiningar, án tillits til líkamlegs eða andlegs atgervis.“

„Nemendur sem eiga erfitt með nám sökum sértækra námsörðugleika, tilfinningalegra eða félagslegra örðugleika og/eða fötlunar, sbr. 2. gr. laga um málefni fatlaðra, nemendur með leshömlun, langveikir nemendur og aðrir nemendur með heilsutengdar sérparfir eiga rétt á sérstökum stuðningi í námi í samræmi við metnar sérparfir.“

Samkvæmt lögum ber grunnskólum pví að koma til móts við námsparfir nemenda með lesblindu ${ }^{8}$ og eiga peir rétt á stuðningi í námi í samræmi við metnar sérparfir, án aðgreiningar. Með skóla án aðgreiningar er verið að vísa í ákveðna hugmyndafræði sem leggja á til grundvallar í allri starfsemi grunnskólanna. Í henni felst að grunnskólar skulu koma til móts við námsparfir hvers og eins nemenda, í nærumhverfi peirra. Đað sé haft sem markmið að allir fái jafngild tækifæri til náms (Mennta- og menningarmálaráðuneytið, 2011).

Í níunda kafla grunnskólalaganna er fjallað um sérfræðipjónustu og stoðkerfi grunnskólanna. Par kemur fram að „,[s]veitarfélög skulu tryggja að sérfræðipjónusta sé veitt 
í grunnskólum, ákveða fyrirkomulag hennar og stuðla að pví að hún fari fram innan grunnskóla. Í sérfræðipjónustu felst annars vegar stuðningur við nemendur og fjölskyldur peirra og hins vegar stuðningur við starfsemi grunnskóla og starfsfólk peirra.“ (Lög um grunnskóla nr. 91/2008, 1. mgr., 40. gr.). Einnig kemur fram að „[1] grunnskólanum skal frá upphafi skólagöngu nemenda unnið að forvarnastarfi með skimunum og athugunum á nemendum til að tryggja peim kennslu og námsaðstoð við hæfi.“ (Lög um grunnskóla nr. 91/2008, 2. mgr., 40. gr).

Í reglugerð um sérfræðipjónustu sveitarfélaga við leik- og grunnskóla og nemendaverndarráð í grunnskólum nr. 584/2010 er nánar fjallað um skipulag og framkvæmd sérfræðipjónustu. Í 3. og 4. gr. í öðrum kafla reglugerðarinnar kemur fram að sveitarstjórn í samráði við skólastjórnendur á að ákveða fyrirkomulag sérfræðipjónustunnar og bera ábyrgð á að viðeigandi pjónusta sé veitt í grunnskólunum. Sveitarfélagið á jafnframt að skilgreina hvernig pað ætlar að standa að sérfræðipjónustu í skólastefnu sveitarfélagsins og tryggja henni fjármagn.

Prátt fyrir að stefna stjórnvalda sé nokkuð skýr um að grunnskólar eigi að bjóða upp á pjónustu fyrir lesblinda er samt ekki skilgreint í lögunum hvað felist í lesblindu né hvers konar úrræði sé um að ræða. Í lögunum kemur einungis fram að slík pjónusta eigi að vera til staðar. Фаð er pví ljóst að samkvæmt stefnu stjórnvalda á pað að vera í höndum sveitarfélaga og grunnskóla að sjá til pess að fram fari skilgreining á pví hverjir teljist vera með lesblindu og hvers konar pjónustu peir eigi rétt á.

Í rannsókn Nönnu Bjarkar Bjarnardóttur (2012) á stefnumótun í málefnum nemenda með lesblindu í grunnskóla kom fram að á undanförnum árum hefur viðhorf gagnvart lesblindum nemendum breyst til batnaðar og margt hefur áunnist varðandi greiningar og skimun. Aftur á móti hefur minni áhersla verið lögð á að próa samhæfð úrræði, aðgerðir og viðeigandi viðbrögð í kjölfar greiningar sem tryggt gætu jafnan aðgang lesblindra nemenda á pjónustu.

Sú pjónusta sem grunnskólarnir veita lesblindum nemendum í dag er mjög mismunandi. Dæmi var um að foreldrar hafi valið sér búsetu eftir pví hvaða pjónusta hafi verið í boði innan grunnskólanna. Ástæðan fyrir pessum mismun var talin eiga rætur að rekja til pess að annars vegar ríkja mjög skiptar skoðanir um hvernig eigi að skilgreina og greina lesblindu, og hins vegar eru áherslur og úrræði skóla og sveitarfélaga gagnvart pessum málaflokki afar mismunandi. Dæmi eru um að skóli telji barn ekki vera með lesblindu, en í greiningu hjá sjálfstætt starfandi sérfræðingi greinist barnið hins vegar með lesblindu. Dá kemur fram í gögnunum að sumir skólar hafa enga starfandi sérkennara á meðan aðrir leggja sérstaka áherslu á sérkennslu og að vera með menntaða sérkennara starfandi við skólann. Ástæðurnar eru meðal annars ólíkar áherslur stjórnenda eða/og skortur á fjármagni og sérpekkingu.

Samkvæmt gögnum rannsóknarinnar pá eru sérkennarar innan skólanna taldir hafa mestu pekkinguna á málefnum nemenda með lesblindu, en svo virðist sem sérkennurum fari par fækkandi og sífellt algengara sé að kennarar starfi sem sérkennarar án pess að hafa til pess menntun. Ýmsar ástæður eru taldar liggja par að baki. Til dæmis kom fram að takmörkuð aðsókn væri í sérkennslunám, en margir höfðu áhyggjur af pví að 
lenging kennaranámsins myndi ýta frekar undir slíka próun. Í peim grunnskólum, par sem sérkennarar starfa, anna peir oft og tíðum ekki eftirspurn, sem hefur leitt til pess аð leitað er eftir pjónustu við lesblinda á almennum markaði. Sérkennarar sinna einnig fáum nemendum en eiga jafnframt rétt á hærri launum. Peir bykja pví vera dýr lausn fyrir sveitarfélögin og eru pess vegna síður ráðnir til grunnskólanna.

Pá kemur fram í gögnunum að sérkennslufyrirkomulagið er stundum talið stangast á við núverandi hugmyndafræði um „skóla án aðgreiningar”. Allir pessir pættir eru taldir hafa ýtt undir pá próun að nú er í ríkara mæli ætlast til pess að hinn almenni kennari sinni nemendum með lesblindu innan grunnskólanna. Í grunnámi kennara er aftur á móti ekki lögð áhersla á pekkingu varðandi lesblindu. Par með virðist litið svo á að ekki purfi að koma til sérpekkingar innan kennarastéttarinnar til að mæta pörfum pessara nemenda. Stefna stjórnvalda í málefnum nemenda með lesblindu er velviljuð stefna. Aftur á móti virðast grunnskólar veita mjög ólíka pjónustu og um leið er eftirlit með gæðum veittrar pjónustu takmarkað. Einnig kemur fram að margir foreldrar leita eftir úrræðum utan skólakerfisins. Par eru um að ræða úrræði sem af fjárhagslegum ástæðum eru ekki aðgengileg fyrir alla foreldra og pví ljóst að markmið stjórnvalda um jöfn tækifæri barna til náms á pessu sviði er í uppnámi.

\section{Stefnumótun í málefni lesblindra á Íslandi 1990-2011}

Með pví að rekja sögu málaflokksins í réttri tímaröð má átta sig á helstu áhrifapáttum varðandi mótun og próun stefnunnar í málaflokknum. Sjá má hvernig áhrif peirra pátta komu fram og hafa leitt til núverandi stöðu í málefnum lesblindra. Hér er fylgt greiningaraðferð sem flokkast undir ferligreining (e. processual analysis) sem Pettigrew (1997) hefur lýst ágætlega. Frásögnin af framvindu stefnumótunarinnar byggist á öflun, skoðun og greiningu á lögum, reglugerðum, skýrslum og öðrum opinberum gögnum, ásamt viðtölum við stjórnmálamenn, embættismenn, sérfræðinga og aðra hagsmunaaðila sem tengdust málaflokknum. ${ }^{9}$

\subsection{Upphafið: Málefni lesblindra kemst á dagskrá stjórnmálanna}

Með fyrstu grunnskólalögunum, sem tóku gildi árið 1974, var lögfest ný stefna í menntamálum í landinu. Samkvæmt lögunum var skólanum nú skylt að tryggja öllum nemendum tækifæri til náms í samræmi við parfir hvers og eins (Helgi Jónasson, 1996). Á pessum tíma höfðu nemendur, sem áttu í erfiðleikum með nám, yfirleitt verið álitnir treggáfaðir og póttu ekki líklegir til langskólanáms. Dessi nýja stefna pótti pví einkennast af meiri jafnréttis- og mannúðarsjónarmiðum en áður hafði pekkst (Helga Sigurjónsdóttir, 1992). Í kjölfar laganna voru gerðar ýmsar breytingar á skólakerfinu í anda pessara nýju markmiða.

Meðal pess sem síðar gerðist var að framhaldsskólarnir voru opnaðir öllum með lagabreytingu árið 1988. Tiltekinn lágmarksárangur á grunnskólaprófi var ekki lengur skilyrði fyrir inngöngu, heldur stóð nemendum, sem höfðu fallið á grunnskólaprófinu, til boða að taka fornám eða svokallaðan núlláfanga (Helga Sigurjónsdóttir, 1992). Samhliða lagabreytingunni jókst verulega aðsókn i framhaldsskólanám. Pá fór að gera vart 
við sig innan framhaldsskólanna hópur nemenda sem átti erfitt uppdráttar vegna lestrarog námserfiðleika. Margir peirra flosnuðu upp úr námi.

Árið 1990 kom út framkvæmdaáætlun um nýja menntastefnu sem nefndist „Til nýrrar aldar“ undir forystu páverandi menntamálaráðherra, Svavars Gestssonar. Eitt af markmiðum stefnunnar var að efla starfs- og námsráðgjöf á öllum skólastigum til að tryggja eðlilega námsframvindu nemenda og koma í veg fyrir brottfall (Menntamálaráðuneytið, 1990). Til pess að starfs- og námsráðgjafar gætu aðstoðað nemendur, sem áttu við námserfiðleika að stríða, purftu peir að vita hvers eðlis vandinn væri. Á pessum tíma voru nokkrar sjálfstætt starfandi greiningarstofur sem greindu lesblindu. Greiningin var kostnaðarsöm og pví erfiður hjalli fyrir efnaminni fjölskyldur. Nokkrir starfs- og námsráđgjafar framhaldsskólanna tóku sig pví saman og prýstu á stjórnvöld um að pessi nemendahópur fengi greiningu, aðstoð og úrræði innan skólakerfisins.

Af stað fór atburðarás sem varð til pess að árið 1992 var sérstök miðstöð, Lestrarmiðstöð Kennaraháskóla Íslands, sett á laggirnar. Pessa ákvörðun tók Ólafur G. Einarsson, páverandi menntamálaráðherra. Átti miðstöðin að vera í faglegu forsvari varðandi pjónustu fyrir pennan hóp. Hugmyndin um lestrarmiðstöð virðist hafa verið komin fram áður, en lestrarerfiðleikar höfðu verið í umræðunni og vangaveltur voru uppi um pörf á greiningartækjum, bættum lestrarkennsluaðferðum og eflingu rannsókna (Menntamálaráðuneytið, 1991). Pá hafði lestrardeild í Fellaskóla nýlega verið lögð niður, en par fór fram kennsla barna með alvarlega lesblindu. Lestrardeildin í Fellaskóla hafði verið fjármögnuð af Fræðsluskrifstofu Reykjavíkur og var bað fjármagn nú lagt til Lestrarmiðstöðvarinnar (Kristín Elva Guðnadóttir, 2003).

Lestrarmiðstöðin tilheyrði Kennaraháskóla Íslands og var skilgreind sem sérstök deild innan skólans. Hlutverk miðstöðvarinnar var prípætt. Í fyrsta lagi að sjá um greiningu og ráðgjöf fyrir nemendur, bæði á grunnskóla- og framhaldsskólastigi, peim að kostnaðarlausu. Í öðru lagi að bjóða upp á greiningu og ráðgjöf fyrir fullorðna einstaklinga og að lokum að vinna að rannsóknum tengdum læsi og lestrarkennslu og miðla áfram pekkingu á pví sviði (Rannveig Lund, 1993).

Fljótlega eftir að stofnunin hóf starfsemi sína varð ljóst að pörfin var mikil par sem langir biðlistar mynduðust eftir greiningu og ráðgjöf. Um leið virkaði miðstöðin sem eins konar faglegur bakhjarl fyrir kennara par sem peir gátu leitað pangað eftir upplýsingum og ráðgjöf („Lestrarmiðstöð annar ekki eftirspurn“, 1999: Rannveig Lund, 1993).

\subsection{Rekstur grunnskólanna flyst frá ríkinu yfir til sveitarfélaganna}

Árið 1996 er rekstur grunnskólanna fluttur frá ríkinu yfir til sveitarfélaganna. Dessi viðamikla stjórnsýslubreyting var hluti af stefnu stjórnvalda um dreifstýringu í anda hugmyndarinnar um nýskipan í ríkisrekstri. ${ }^{10}$ Með pví að færa rekstur grunnskólanna nær nemendum var talið að hægt væri að ná fram hagkvæmari rekstri og betri pjónustu. Lagt var upp með að menntamálaráðuneytið færi með markmiðasetningu og eftirlit með skólastarfinu, en skólarnir hefðu fjárhagslegt sjálfstæði í samvinnu við sveitarfélögin og ákvörðunarvald varðandi hvaða skipulagi og starfsaðferðum væri beitt til pess að ná settum markmiðum (Mennta- og menningarmálaráðuneytið, 1994). 
Í kjölfar flutningsins áttu sér stað ýmsar kerfisbreytingar innan stjórnsýslunnar varðandi grunnskólana. Đar á meðal voru breytingar, sem sneru að sérfræðipjónustu við grunnskólana, par sem sveitarfélögin áttu nú sjálf að fjármagna og bera ábyrgð á slíkri pjónustu. Fræðsluskrifstofur, sem störfuðu í hverju fræðsluumdæmi á vegum ríkisins, voru lagðar niður og grunnur lagður að stofnun svokallaðra skólaskrifstofa á vegum sveitarfélaganna. Pannig átti sú pjónusta sem fræðsluskrifstofurnar höfðu veitt að standa áfram til boða en útfærslan átti að vera í höndum hvers sveitarfélags (Mennta- og menningarmálaráðuneytið, 1994).

prátt fyrir að rekstur grunnskólanna hafði verið fluttur yfir til sveitarfélaganna var Lestrarmiðstöðin áfram starfandi á vegum ríkisins. Đá kom upp sú staða að Kennaraháskóli Íslands var að veita sveitarfélögunum pjónustu á vegum ríkisins. Par sem sveitarfélögin áttu, eins og fyrr segir, að fjármagna sérfræði pjónustu fyrir grunnskólana sjálf, var litið svo á að pað fjármagn, sem rann til Lestrarmiðstöðvarinnar, væri einungis ætlað framhaldskólanemum. Upphaflega hafði pjónustan verið bæði grunn- og framhaldskólanemum að kostnaðarlausu, en nú var grunnskólanemendum gert að greiða fyrir bjónustuna.

Árið 2002 ákváðu stjórnvöld síðan endanlega að hætta fjárveitingum sem eyrnamerktar höfðu verið Lestrarmiðstöðinni til Kennaraháskóla Íslands. Var pað lagt í hendur skólans að ákveða hvort hann vildi halda áfram að veita pessa pjónustu. Kennaraháskólinn var ekki tilbúinn til pess að leggja til aukið fé af eigin fjárveitingum í starfsemi miðstöðvarinnar. Kennaraháskólinn taldi pað ekki vera í sínum verkahring að veita pessa pjónustu og vildi heldur nýta fjármagn sitt til fræðslustarfa og kennslu. Lestrarmiðstöðin var pví lögð niður.

Hávær mótmæli áttu sér stað við lokun miðstöðvarinnar og margir óttuðust um pá faglegu forystu sem hafði myndast með starfsemi hennar. Sveitarfélögin voru mjög misjafnlega í stakk búin til pess að veita pessa pjónustu, bæði vegna skorts á pekkingu og fjármagni. Margir grunnskólar purftu pví í kjölfarið að leita eftir greiningu og úrræðum á einkamarkaði fyrir pjónustu við nemendur með lesblindu (Gunnar Hersveinn, 2002).

\section{3 pjónusta við lesblinda kemst á dagskrá stjórnvalda}

Við flutning grunnskólanna frá ríki til sveitarfélaga hafði orðið breyting á verkaskiptingunni milli ríkis og sveitarfélaga. Verkefni ríkisins var nú að vinna að pví að skilgreina betur markmiðið með pjónustunni fyrir nemendur með lesblindu innan skólakerfisins. Hér verður í stuttu máli rakin aðkoma tveggja ráðherra að stefnumörkun í málaefnum lesblindra á tímabilinu 1996-2008.

Samhliða flutningi grunnskólanna til sveitarfélaganna byrjar ríkið að beita sér af auknum krafti við að betrumbæta pjónustuna við lesblinda nemendur innan skólakerfisins. Sú stefnumótunarvinna var unnin í anda Salamanca-yfirlýsingarinnar ${ }^{11}$ undir forystu páverandi menntamálaráðherra, Björns Bjarnasonar.

Árið 1997 skipaði Björn nefnd til pess að fjalla um málefni lesblindra. Niðurstöður nefndarinnar komu fram í skýrslu sem gefin var út sama ár. Í henni kemur fram að mjög skiptar skoðanir ríktu meðal fræðimanna um hvernig eigi að skilja, skilgreina og meta 
lesblindu. Algengt væri að nemendur, sem hefðu óskað eftir greiningu, fengju ólíka úrskurði eftir pví hvert peir hefðu leitað. Í skýrslunni er bent á mikilvægi pess að skipulag, skilgreiningar og vinnubrögð meðal skólanna yrðu samræmd til að nemendur með lesblindu fengju greiningu og par með viðeigandi kennslu og úrræði. Einnig var bent á mikilvægi pess að pekking á pessum málaflokki yrði efld, sérstaklega meðal kennara (Grétar L. Marinósson o.fl., 1997).

Dau ólíku sjónarmið, sem ríkja innan málaflokksins, koma einnig fram í tengslum við próun og framkvæmd lesskimunarprófs sem ofangreind nefnd lagði til að yrði innleitt í grunnskólunum. Markmiðið með prófinu var að finna pá nemendur sem voru lesblindir og veita peim snemmtækar stuðningsaðgerðir. Pessi hugmynd varð síðan hluti af skólastefnu yfirvalda (Menntamálaráðuneytið, 1998; 1999). Árið 1998 var pví sérstök framkvæmdanefnd skipuð til að fara með áframhaldandi próun á slíku prófi. Ekki náðist samstaða um lesskimunarprófið meðal sérfræðinga, sem leiddi til pess að nefndin hætti störfum og ráoherra tók málið í sínar hendur (Björn Bjarnason, 2000). Í peim tilgangi að stuðla að aukinni samvinnu meðal séfræðinga og skapa samræmda og markvissa pjónustu fyrir pennan nemendahóp stóð menntamálaráðuneytið fyrir málpingi um málaflokkinn árið 2000 („Lestrarerfiðleikar furðu algengir“, 2000: Mennta- og menningarmálaráðuneytið, 2000).

Árið 2003 vou markmið lesskimunarprófsins sett í reglugerð um sérfræðipjónustu skóla. Grunnskólar áttu skv. reglugerðinni að kanna hvaða nemendur ættu hugsanlega í erfiðleikum með lestur á fyrstu árum skólagöngunnar og bregðast við með kerfisbundnum hætti og reglulegri eftirfylgni. Sérfræðipjónusta sveitarfélaganna átti að veita skólanum aðstoð varðandi greiningarprófin og veita kennurum leiðbeiningar varðandi niðurstöður peirra og áframhaldandi úrræði. Einnig var gert ráð fyrir að menntamálaráðuneytið færi með eftirlit með pjónustunni og kalli eftir upplýsingum frá sveitarfélögunum um pessi málefni hjá einstökum skólum á tveggja ára fresti (Reglugerð um breytingar á reglugerð um sérfræðipjónustu skóla nr. 905/2003).

Árið 2004 fól menntamálaráðuneytið skólapróunarsviði kennaradeildar Háskólans á Akureyri að gera úttekt á lesskimunarprófinu og kanna hvort pað standist kröfur, og hvort og hvernig pað er notað meðal grunnskólanna. Niðurstöðurnar gefa til kynna að lesskimunarprófið væri gott tæki til pess að finna nemendur sem eiga í lestrarerfiðleikum. Pá kom fram að langflestir grunnskólar leggja prófið fyrir nemendur og nýta niðurstöðurnar við áframhaldandi skipulag á lestrarkennslu, m.a. varðandi ákvörðun um sérkennsluúrræði og mótun á einstaklingsnámskrá. Aftur á móti virðast kennara ekki nota tillögur að úrræðum sem fylgja með prófinu í hugmyndahefti. Đá kom fram að pau mörk sem væru notuð til viðmiðunar um lestrarerfiðleika væru mjög ólík meðal grunnskóla. Mælst var til pess að viðmiðunarmörkin væru samrýmd og um leið var bent á mikilvægi pess að pau yrðu jafnframt rýmri (Guðmundur Engilbertsson og Rósa Eggertsdóttir, 2004).

Í lok nóvember árið 2006 kemst málaflokkurinn aftur á dagskrá hjá páverandi menntamálaráðherra, porgerði Katrínu Gunnarsdóttur. Á pessu ári hafði komið upp umræða varðandi stöðu lesblindra nemenda í tengslum við töku samræmdra prófa í grunnskóla. 


\section{STJÓRNMÁL \\ STJÓRNSÝSLA}

Viðbrögð menntamálaráðherrans við peirri umræðu birtist í grein í Morgunblaðinu. Par kom fram að umræðan um pessi málefni sé oft á villigötum, en prátt fyrir pað sé pörf á skýrari stefnu í pessum málaflokki svo að veita megi lesblindum nemendum betri pjónustu innan skólakerfisins (Porgerður Katrín Gunnarsdóttir, 2006). Skipaði ráðherrann nefnd til að vinna að tillögum varðandi pjónustu fyrir nemendur með lesblindu og aðra lestrarörðugleika í grunn- og framhaldskólum.

Skýrsla nefndarinnar kom út árið 2007. Par voru lagðar fram ýmsar tillögur til hagsbóta fyrir lesblinda nemendur. Nefndin átti meðal annars að skoða hvernig hægt væri að efla pekkingu og ráðgjöf fyrir kennara varðandi pennan málaflokk, auk pess að kanna hvernig staðið væri að kennaranáminu varðandi lestrarkennslu og lestrarerfiðleika. Fram kom að fræðslan virtist vera takmörkuð meðal kennaranema og pá sérstaklega varðandi lestrarerfiðleika. Par sem pekkingin var takmörkuð innan skólanna benti nefndin á mikilvægi pess að kennarar hefðu aðgang að slíkri sérfræðipekkingu, ásamt kennsluráðgjöf og stuðningi í starfi sínu með lesblindum nemendum. Bent var á að slík pjónusta ætti að vera í höndum sérfræðipjónustu sveitarfélaganna eða skólaskrifstofa par sem pær væru fyrir hendi. Aftur á móti pótti ljóst að sveitarfélögin væru misjafnlega í stakk búin til að mæta peim kröfum. Í skýrslunni kemur einnig fram að samkvæmt óbirtri athugun ráðuneytisins skilgreina sveitarfélögin enn með ólíkum hætti hvenær nemendur teljast eiga við lesblindu að stríða og upplýsingum um fjölda nemenda, sem eiga í lestrarerfiðleikum, er ekki safnað saman með reglubundnum hætti (Menntamálaráðuneytið, 2007).

Árið 2008 voru síðan sett ný grunnskólalög nr. 91/2008 sem eru pau lög sem gilda í dag. Eins og fyrr segir er par að finna skýr ákvæði pess efnis að koma skuli til móts við námsparfir nemenda með lesblindu og að peir eigi rétt á stuðningi í námi í samræmi við metnar sérparfir. Đá eiga sveitarstjórnir í samráði við skólastjóra að ákveða fyrirkomulag pjónustunnar og bera ábyrgð á að hún sé veitt.

Árið 2010 komu síðan út tvær reglugerðirr ${ }^{12}$ par sem pjónustan er útfærð nánar og eru par að finna ýmis tilmæli nefndarinnar sem Pogerður Katrín skipaði árið 2006. Aftur á móti er ekki skilgreint í lögunum hvað felst í lesblindu (sértækum námsörðugleikum og leshömlun), né hvers konar pjónustu á að veita pessum nemendum. Árið 2011 kom jafnframt út ný aðalnámskrá grunnskóla. Đar er að finna tilmæli um að grunnskólarnir hafi aðgang að greiningar- og matstækjum á borð við stöðluð lestrarpróf og lesskimunarpróf, til pess að hægt sé að spá fyrir um námserfiðleika nemenda og bregðast við með snemmtækri íhlutun. Frekari útfærslu á lögunum er ekki að finna í aðalnámskránni varðandi pennan málaflokk. Đar kemur pó fram að stefna stjórnvalda sé að sveitarfélög og grunnskólar fái töluvert svigrúm til pess að aðlaga grunnskólanámið að pörfum nemenda á hverjum stað (Mennta- og menningarmálaráðuneytið, 2011).

\section{Umræða}

Í rannsókn Nönnu Bjarkar Bjarnadóttur má finna heildstæða lýsingu og greiningu á stefnumótun og stöðu í málefnum lesblindra á Ísland. Hér er hins vegar tekinn afmarkaður sögupráđur í rannsókn Nönnu sem lýsir próun pekkingar innan málaflokksins og sú próun sett í víðara samhengi stjórnmála og stefnumótunar á tímabilinu 1990 til 2007. 
Gerður er samanburður á stöðu og áhrifum sérfræðilegrar pekkingar á stefnumótun í málefnum lesblindra annars vegar og stefnumótun í málefnum sjúkrahúsanna í Reykjavík hins vegar. Tilgangurinn með pví að skoða og greina samspil stjórnmála, pekkingar og stefnumótunar hér er tvípættur. Í fyrsta lagi að auka skilning á opinberri stefnumótun á Íslandi almennt og í öðru lagi að skoða pennan málaflokk sérstaklega út frá nýju sjónarhorni ef pað mætti verða til pess að ræða gamlar og nýjar spurningar í nýju ljósi og örva par með almenna umræðu um málefni nemenda með lesblindu á Íslandi.

Hugtökin við greiningu og samanburð eru sótt í rannsóknir Kingdons og Tuohy. Par gegna hugtökin „samstaða“, sem sprottin er af sampjöppun pekkingar og „pólitískur einhugur" lykilhlutverki. Skilningur á áhrifum samstöðu eða samstöðuleysis annars vegar og samhengi slíkra áhrifa við stefnumörkun stjórnvalda hins vegar varpa hér ljósi á afleiðingar pessa samspils fyrir stefnumótunina í heild sinni og niðurstöður hennar.

раð vekur athygli í próun pessa málaflokks eins og hann er rakinn hér að vandamál lesblindra kemst á dagskrá í kjölfar pess að framhaldsskólarnir stóðu öllum nemendum úr grunnskólum til boða eftir lagabreytinguna árið 1988. Đá birtist nemendahópur innan framhaldsskólanna sem átti mjög erfitt uppdráttar par og brottfall nemenda fór vaxandi. Algengt var að nemendur kæmu í framhaldsskóla án pess að hafa fengið greiningu á lesblindu í grunnskóla. Framhaldsskólarnir höfðu ekki fengist við slíka nemendur áður, líklega vegna pess að flestir peirra höfðu farið beint út á vinnumarkaðinn að loknu grunnskólanámi.

Með nýrri menntastefnu árið 1990 er starfsemi náms- og starfsráðgjafar í framhaldsskólum efld, m.a. til að draga úr brottfalli nemenda. Раð er síðan vegna prýstings frá starfs- og námsráðgjöfum innan framhaldsskólanna að Lestrarmiðstöð Kennaraháskóla Íslands var stofnuð. Samhliða aukinni umræðu um mikilvægi pess að bregðast við lesblindu sem fyrst, kom fram aukinn prýstingur á grunnskólanna að skima eftir nemendum sem hugsanlega væru lesblindir og ganga úr skugga um að peir fengju greiningu. Síðar var fjárhagslegum hvötum til að stemma stigu við brottfalli nemenda úr framhaldsskólum háttað pannig að fjárveitingar voru bundnar við fjölda nemenda sem preyttu próf. Par með sá hver skóli sér hag í pví að halda í pá nemendur sem á annað borð hófu nám við skólann. Slíkur hvati var ekki til staðar innan grunnskólanna par sem par var lögboðin skólaskylda.

Með Lestrarmiðstöðinni var búin til lausn sem einnig fól í sér möguleikann á að sameina á einum stað starfsfólk með pekkingu og reynslu af aðferðum við að greina og leysa úr vandamálum lesblindra nemenda á Íslandi. Slík stofnanabinding á verklagi býður upp á sampjöppun reynslu og pekkingar sem er forsenda rannsókna og par með á stöðlun hæfni og aðferða sem byggðar eru á gagnreyndri pekkingu. Dróun sérfræðilegrar pekkingar með pessum hætti er í raun uppbygging á fagskrifræðinu eins og Mintzberg lýsir pví. Fagskrifræði á að tryggja samhæfingu aðferða og par með gæði og öryggi pjónustunnar fyrir notendur. En fagskrifræði getur líka tryggt jafnræði meðal notenda að pví marki að sams konar vandamál fái sams konar meðferð. Eitt pekktasta dæmi um fagskrifræði, sem veitir öllum einstaklingum pjónustu með einum eða öðrum hætti á einhverjum tíma æviskeiðsins, eru sjúkrahús. Viðfangsefni háskólasjúkrahúsa eru ekki einungis 
að veita veiku og slösuðu fólki pjónustu, heldur einnig að próa og staðla gagnreynda pekkingu með rannsóknum og pjálfun heilbrigðisstarfsfólks og tryggja gæði og öryggi pjónustunnar. Grunnurinn að uppbyggingu og viðhaldi slíkrar pekkingar og hæfni fæst með endurtekningum, sem pýðir að pví fleiri sjúklingar með sams konar vandamál pví meiri reynsla og betri skilningur, pekking og hæfni safnast saman innan stofnunar og hjá starfsfólki.

раð er sameiginlegt með stefnumótun innan pessara málaflokka að hún átti sér að mestu stað á tímabili ríkisstjórna Sjálfstæðisflokks og Framsóknarflokks, p.e. á tímabilinu 1990-2007. ${ }^{13}$ Раð sem einkenndi petta tímabil öðru fremur er innleiðing nýskipunar í ríkisrekstri sem var stýrt frá fjármálaráđuneytinu undir pólitískri yfirstjórn Sjálfstæðisflokksins. Nýskipaninni fylgdi dreifstýring í öllum myndum, p.e. flutningur verkefna til sveitarfélaga og markaðsvæðing hvort heldur sem var í formi útvistunar verkefna eða einkavæðingar. Mikil áhersla var á pessari stefnu ríkisstjórnanna og henni fylgt fast eftir yfir langt og samfellt tímabil. Hið ytra pólitíska samhengi með peim stefnum, straumum, áherslum og forgangsröðun, sem pví samhengi fylgdi, var pví eitt og hið sama allan tímann. Eins og Tuohy bendir á, pegar saman fer nægilegur pólitískur einhugur og skýr forgangsröðun yfir samfellt tímabil, aukast líkurnar á pví að stefnumál stjórnvalda nái fram að ganga. En pað eitt og sér er pó ekki nægilegt.

एаð sem aftur á móti var ólíkt með pessum málaflokkum var að frá og með árinu 1990 voru heilbrigðismál alfarið á hendi ríkisins en grunnskólinn, og par með málefni nemenda með lesblindu í grunnskólum, fluttist á tímabilinu yfir til sveitarfélaganna. Stigveldið sem farvegur ákvarðana í opinberri stefnumótun sjúkrahúsanna í Reykjavík sameinaðist og styrktist enn frekar á pessum tímabili með yfirtöku ríkisins á allri sjúkrahúspjónustu í Reykjavík. Með flutningi grunnskólans til sveitarfélaganna veiktist stigveldið sem farvegur stefnumótunar og stefnumótandi ákvarðanavald var nú orðið dreifðara. Prátt fyrir að stefnumarkandi ákvarðanir um markmið og stefnu stjórnvalda hafi verið áfram hjá ríkinu og á hendi ráðuneytisins var stefnumótun framkvæmdarinnar að mestu hjá sveitarfélögunum sem fóru með faglega og rekstrarlega ábyrgð á málefnum grunnskólanna. Pannig var stefnumótandi framkvæmd á málefnum nemenda með lesblindu nú komin í hendur margra sveitarfélaga. Með sameiningu sveitarfélaga fækkaði peim á tímabilinu - pau voru 170 árið 1995 en voru orðin 101 árið 2005. Fjöldi sveitarfélaga með yfir 10.000 íbúa stóð í stað á tímabilinu. Fjölda sveitarfélaga með milli 1000 og 10.000 íbúa fækkaði um eitt, en sveitarfélögum með undir 1000 íbúa hafði fækkað úr 137 árið 1995 í 69 á árinu 2005 (Hagstofa Íslands, e.d.). Dótt mörg sveitarfélög sameinist um rekstur grunnskóla eða um sérfræðipjónustu skólanna pá voru stefnumótandi ákvarðanir í málefnum grunnskólans engu að síður orðnar dreifðari.

Eins og fyrr segir pá er pað sameiginlegt með skipulagsformum skóla og sjúkrahúsa að hér er á ferðinni fagskerifrađi. Par gerir framkvæmd pjónustunnar ráð fyrir sérfraðipekekingu, p.e. að starfsmenn hafi fengið tiltekna pjálfun og búi yfir viðeigandi hæfni til að geta tekið ákvarðanir viðvíkjandi pjónustu í beinum samskiptum við notandann. Раð sem greinir að stefnumótunina, sem hér er til skoðunar og stefnumótun sjúkrahúsanna í Reykjavík, er að undir lok tíunda áratugarins náðist að mynda nægilega samstöðu meðal 
lakna um mikilvægi pess að pjappa saman á einum stað, á Landspítala-Háskólasjúkrahúsi, nægilegum fjölda sjúklinga og heilbrigðisstarfsfólks til að mynda pann „krítíska massa" sem mikilvægur er til að tryggja gæði og öryggi pjónustunnar með uppbyggingu á gagnreyndri pekkingu. Á sama tíma var að fjara undan Lestrarmiðstöð Kennaraháskólans par sem pó hefði átt að vera vísir að skipulagðri samhæfingu pekkingar, reynslu og aðferða til að tryggja gæði og öryggi pjónustunnar við nemendur með lesblindu. Á meðan stefnt var í átt til sérhæfingar innan sjúkrahúspjónustunnar var stefnan í átt frá sérhæfingu innan skólakerfisins eins og hún virðist birtast í hugmyndafræðinni um „skóla án aðgreiningar“ innan grunnskólanna. Prátt fyrir tilraunir ríkisins til að marka stefnuna með reglugerðarsetningu pá fór saman að stigveldið innan málaflokksins var orðið veikara, stefnumótandi ákvarðanir komnar á fleiri hendur, ósamstada ríkti meðal sérfradinga og skortur var á pekekingu innan kennarastéttarinnar sem gerði pað að verkum að stjórntæki ráðherrans, p.e. breytingar á reglugerð um sérfræðipjónustu skóla nr. 905/2003 dugði ekki til. Opinber umræða innan málaflokksins árið 2007 bendir til pess að tilmæli ráðherrans í reglugerðinni frá 2003 höfðu ekki gengið eftir (Anna Guðmundsdóttir, Guðmundur S. Johnsen og Hermundur Sigmundsson, 2007). Ákvörðun Dorgerðar Katrínar Gunnarsdóttur páverandi menntamálaráðherra um að skipa nefnd til pess að fjalla um málaflokkinn árið 2006, styður pessa ályktun (Menntamálaráðuneytið, 2007; Porgerður Katrín Gunnarsdóttir, 2006).

pá er sameiginlegt með málaflokkum mennta- og heilbrigðismála að kerfin eru byggð upp af starfsstöðvum um allt land. Hins vegar hefur verið lögð áhersla á að byggja upp sérfræðipjónustu samhliða próun sérfræðilegrar pekkingar á fáum stöðum innan heilbrigðiskerfisins og trónir Landspítali-Háskólasjúkrahús par sem musteri pekkingarinnar (e. centre of excellence) sem á í pekkingarpróunarlegu tilliti að pjónusta landið allt. Enga slíka miðstöð pekkingarpróunar á sviði sérfræðipjónustu við nemendur með lesblindu var að finna eftir að Lestrarmiðstöðinni var lokað árið 2002. Margt bendir reyndar til pess að sem slík hafi Lestrarmiðstöðin ekki náð að mynda nægilega öfluga og afgerandi forystu par sem mjög skiptar skoðanir ríktu t.d. um skilning og skilgreiningu á lesblindu. Skilningurinn og skoðanirnar voru svo mismunandi að ekki náðist samstaða í nefnd ráðherrans um framkvæmd skimunarprófs árið 1998 og tók ráðherra pví málið í sínar hendur. Баð bendir til pess að prátt fyrir að Lestrarmiðstöðin hafi pá verið búin að starfa í 6 ár hafi ekki tekist að stofnsetja verklag og aðferðir með peim hætti að nægilegur pekkingargrunnur hafi náð að skapast til að samhæfa aðgerðir og mynda sameiginlegan skilning og viðmið um lesblindu. Skýr fagleg forysta innan málaflokksins var pví ekki til staðar. Ástæðuna má einnig rekja til pess að miðstöðin réð ekki við pá eftirspurn sem myndaðist strax í byrjun starfseminnar. Fljótlega myndaðist langur biðlisti af einstaklingum sem höfðu pörf fyrir greiningu og ráðgjöf og pví var ljóst að miðstöðin hefði purft aukna fjárveitingu til pess að mæta pörfinni samhliða pekkingarpróun.

Sá skriðpungi sem fylgdi innleiðingunni á nýskipan í ríkisrekstri leiddi til pess að aðgerðir ríkisins í peim efnum voru í andstöðu við pá pekkingu sem pó var að myndast innan kerfisins og komu fram með hugmyndinni um mikilvægi „,snemmtækrar íhlutunar“. Sú ákvörðun stjórnvalda að leggja niður sérstaka fjárveitingu til Lestrarmiðstöðvarinnar 


\section{STJÓRNMÁL \& \\ STJÓRNSÝSLA}

var liður í verkaskiptingu milli ríkis og sveitarfélaga. Đar með var litið svo á að sveitarfélögin ættu sjálf að fjármagna sérfræðipjónustu fyrir grunnskólana. Баð fjármagn sem rann til Lestrarmiðstöðvarinnar var pví einungis ætlað framhaldsskólanemum en upphaflega hafði pjónustan par verið bæði grunn- og framhaldsskólanemum að kosntaðarlausu. Eftir pessa ákvörðun var grunnskólanemendum gert að greiða fyrir pjónustuna. M.ö.o. hér var hvatinn, sem studdi við hugmyndina um „snemmtæka íhlutun“, afnuminn. Kennaraháskóla Íslands var hins vegar látið eftir pað hlutverk að slá starfsemina af. Segja má að par hafi skólinn látið pað tækifæri ganga sér úr greipum að byggja upp miðstöð pekkingarpróunar innan menntakerfisins með sambærilegri tengingu við akurinn og Landspítali- Háskólasjúkrahús, p.e. með nánum tengslum milli klínískra og vísindalegra rannsókna.

Pá er pað einnig líkt með pessari stefnumótun í málefnum lesblindra og málefnum sjúkrahúsanna í Reykjavík að í báðum tilvikum sköpuðust betri skilyrði fyrir starfsemi á markaði. Í báðum tilvikum leiddi stefnumótun stjórnvalda til aukinnar markaðs- og einkavæðingar á pjónustunni. Hins vegar varð sú próun með ólíkum hætti.

pótt nægileg samstaða hafi náðst meðal lækna um sameiningu sjúkrahúsanna í Reykjavík undir formerkjum sampjöppunar sérgreina til viðhalds pekkingar og rannsókna pá voru ekki allir læknar ánægðir. En til að ná markmiðinu um sameiningu sjúkrahúsanna í Reykjavík og draga úr vaxandi óánægju sérgreinalækna, sem par störfuðu, bjuggu stjórnvöld til undankomuleið (e. exit option) (Hirschman, 1969). Í kjölfarið stórjókst starfsemi sérgreinalækna á einkastofum út í bæ og pað svo mjög að hér eins og í tilviki Lestrarmiðstöðvarinnar voru aðgerðir stjórnvalda í andstöðu við pau faglegu sjónarmið sem lágu að baki sameiningu sjúkrahúsanna um myndun hins „krítíska massa sjúklinga og starfsfólks“ til að tryggja gæði og öryggi pjónustunnar.

Við flutning grunnskólans til sveitarfélaganna varð röskun á stoðpjónustu skólanna. Minni sveitarfélögum reyndist erfiðara að fjármagna sérfræðipjónustu við grunnskólann. Vegna mismunandi getu sveitarfélaganna til að veita pessa pjónustu, bæði í fjárhagslegu og pekkingarlegu tilliti, purftu margir skólar að leita til sérfræðinga á almennum markaði. Óánægðir foreldrar, sem töldu sig ekki fá pá pjónustu sem peir purftu fyrir börnin sín innan skólanna, leituðu pá sjálfir út á markaðinn eftir pjónustu. Sérhæfing innan skólanna á málefnum nemenda með lesblindu var víkjandi. Vísbendingar eru um að kostnaðurinn hafi pó ekki verið eina ástæðan heldur hafi stefna stjórnvalda um „skóla án aðgreiningar" haft pau áhrif að sérhæfing í formi sérkennslu innan almenna skólans var látin víkja. M.ö.o. stefnumótun stjórnvalda í málefnum lesblindra leiddi til pess að aukið svigrúm skapaðist til markaðsvæðingar á pjónustu og úrræðum fyrir nemendur með lesblindu.

Staða sjúklinga og lesblindra nemenda m.t.t. upplýsinga og öryggis á svona markaði er afar misjöfn hér á Íslandi. Sérgreinalæknar purfa lækningaleyfi til að fá að starfa við sína sérgrein og samning við ríkið til að geta starfað á einkastofum út í bæ. Deim er gert að fylgja klínískum leiðbeiningum sem byggðar eru á gagnreyndri pekkingu og lúta eftirliti landlæknis. Djónusta við fólk með lesblindu á markaði er hvorki háð slíkum leyfisveitingum né klínískum leiðbeiningum og ekkert eftirlit er með pví að sú pjónusta, sem veitt 
er, sé við hæfi, enda engir samhæfðir staðlar eða önnur tæki til að meta áhrif og gæði pjónustunnar. Slíkur markaður sérfræðinga innan menntakerfisins á meira sameiginlegt með markaði fyrir fæðubótarefni eða óhefðbundnar lækningar en með pjónustu lækna innan heilbrigðiskerfisins.

\section{Lokaorð}

Meginniðurstöður pessa samanburðar milli stefnumótunarferlis innan heilbrigðiskerfisins og stefnumótunarferlis innan menntakerfisins má setja fram með einföldum hætti eins og gert er í Töflu I.

Tafla 1. Samanburđur milli stefnumótunarferlis innan heilbrigðiskerfisins og menntakerfisins

\begin{tabular}{|c|c|c|}
\hline TAFLA I & $\begin{array}{l}\text { Stefnumótun í málefnum } \\
\text { sjúkrahúsanna í Reykjavík }\end{array}$ & $\begin{array}{l}\text { Stefnumótun í málefnum lesblindra } \\
\text { innan grunnskólanna }\end{array}$ \\
\hline Stigveldi & $\begin{array}{l}\text { Stigveldið var óskipt og miðstýring } \\
\text { var mikil. Auðveldara var að mynda } \\
\text { pólitíska samstöðu og einhug um } \\
\text { stefnumörkun og stefnumótun í } \\
\text { málefnum sjúkrahúsanna. }\end{array}$ & $\begin{array}{l}\text { Stigveldinu var skipt upp og dreifstýring } \\
\text { varđ mikil. Erfiðara var að mynda } \\
\text { pólitíska samstöđu eđa einhug } \\
\text { um stefnumörkun og framkvæmd } \\
\text { stefnu í málefnum lesblindra innan } \\
\text { grunnskólanna. }\end{array}$ \\
\hline $\begin{array}{l}\text { Sérfræðđingasamfélag/ } \\
\text { fagskrifræð̇ }\end{array}$ & $\begin{array}{l}\text { Stađa pekkingar var sterk og öflugt } \\
\text { fagskrifræđi var til stađar. En samstađa } \\
\text { innan sérfræđingasamfélgsins hafði } \\
\text { veikst vegna mismunandi hagsmuna. }\end{array}$ & $\begin{array}{l}\text { Veikt fagskrifræđi innan málaflokksins. } \\
\text { Lítil sem engin samstađa ríkti innan } \\
\text { sérfræđingasamfélagsins og stađa } \\
\text { pekkingar var pví veik. }\end{array}$ \\
\hline Markaður & $\begin{array}{l}\text { Opnað var á möguleika til aukinnar } \\
\text { starfsemi á markađi. }\end{array}$ & $\begin{array}{l}\text { Tækifæri opnuđust til ađ bjóđa pjónustu } \\
\text { á markađi. }\end{array}$ \\
\hline
\end{tabular}

Úr pessari töflu má lesa að á meðan miðstýring ríkti innan heilbrigðiskerfisins var auðveldara að mynda pólitíska samstöðu um stefnu stjórnvalda um sameiningu sjúkrahúsanna. Sú samstaða um stefnumörkunina náði með tímanum að nýta sér ósamstöðu innan læknastéttarinnar sem rekja mátti til ólíkra hagsmuna meðal lækna. Með pví að skapa tækifæri fyrir óánægða lækna til að stunda lækningar á stofum sínum utan sjúkrahúsanna tókst stjórnvöldum að koma fram stefnu sinni um sameiningu sjúkrahúsanna í framkvæmd. En með aukinni markaðsvæðingu á pjónustu lækna var í raun grafið undan hugmyndinni um sampjöppun pekkingar og reynslu sem var bakgrunnur sameiningar sjúkrahúsanna par sem pjónusta lækna varð dreifðari.

Aftur á móti ríkti pólitísk samstaða innan menntakerfisins að baki dreifstýringar innan grunnskólakerfisins, p.e. að flytja rekstur grunnskólanna frá ríkinu yfir til sveitarfélaganna. Бað leiddi til pess að stefnumótandi ákvarðanavald um framkvæmd stefnunnar varð dreifðara og par af leiðandi veiktust stefnumarkandi áhrif ríkisins. Pegar flutningur grunnskólans til sveitarfélaganna átti sér stað var ekki búið að mynda sameiginlegan skilning innan sérfræðingasamfélagsins á málefnum nemenda með lesblindu. Af pví leiddi að móttækileiki skólanna og sveitarfélaganna fyrir hugmyndum sem liggja 
að baki stefnumörkunar ríkisins í málaflokknum var takmarkaður og pað seinkaði árangursríkri innleiðingu peirrar stefnu. Dreift stefnumótandi ákvarðanavald í málefnum grunnskólanna og samstöðuleysi innan sérfræðingasamfélagsins hefur samanlagt veikt getu menntakerfisins til að samhæfa reynslu og byggja upp gagnreynda pekkingu og hæfni til að mæta pörfum nemenda með lesblindu. Mismunandi geta sveitarfélaganna til að koma til móts við nemendur með lesblindu, skortur á samhæfðri lausn á borð við Lestrarmiðstöðina og óánægja foreldra nemenda með lesblindu skapaði tækifæri til að bjóða skólum og foreldrum nemenda með lesblindu pjónustu á markaði.

Í báðum tilvikum, p.e. innan menntakerfisins og innan heilbrigðiskerfisins má sjá að stefnumótunin hefur tekið á sig form stefnureks par sem framkvæmd stefnumótunarinnar leiðir til pess að áhrif stefnunnar hafa ekki náð að endurspegla yfirlýst markmið stjórnvalda.

Markmið stjórnvalda í grunnskólalögunum er að tryggja jöfn tækifæri nemenda til náms. Pessi skoðun höfunda á stefnumótun í málefnum lesblindra hefur vakið upp spurningar um jöfnuð meðal nemenda með lesblindu innan grunnskólakerfisins. Rannsóknin sýnir að mismunandi geta sveitarfélaganna til að koma til móts við nemendur með lesblindu skapar ójöfnuð. Sá ójöfnuður skýrist að einhverju leyti af landfræðilegum ástæðum. Фаð að ekki er brugðist við peim ójöfnuði af hálfu stjórnvalda með samhæfðri lausn fyrir skólana í landinu hefur leitt til efnahagslegs ójöfnuðar. Pá vaknar sú spurning hvort framkvæmdin á hugmyndinni um ,skóla án aðgreiningar“ geti skapað ójöfnuð.

Greina má ákveðna pversögn í hugmyndafræðinni um „skóla án aðgreiningar“ og stefnunni um „einstaklingsmiðað nám“. Í fyrsta lagi ríkir ákveðin hræðsla við pað að útfæra einstaklingsmiðað nám með einhverju sem flokkast getur undir „sérkennslu“ af ótta við áhrif pess að beita sérstökum kennsluaðferðum við einstaka nemendur innan hins almenna skóla, p.e. „stimplun“. Í öðru lagi er framkvæmdin á einstaklingsmiðuðu námi kostnaðarsöm og pað er á valdi skólastjórnenda að ákveða forgangsröðun í hverjum skóla. Við petta getur orðið til úrræðaleysi innan skólanna sem aftur getur snúið greiningu á nemendum með lesblindu upp í andhverfu sína. Pá er greiningin í sjálfu sér ekki vandamálið sem parf að leysa heldur úrræðaleysið. M.ö.o. pegar greiningu fylgja ekki leiðbeiningar um viðurkennt og viðtekið ferli sem getur tekið við til að mæta peim vanda, sem greinist, pá verður til nýtt vandamál sem er skólinn sjálfur. Pegar foreldrum finnst skólinn bregðast barninu sínu reyna sumir peirra að leita annað eftir lausn. En pað er lausn sem er hvorki tryggð með tilliti til gæða og árangurs né öllum fær af fjárhagslegum ástæðum. Pannig getur hugmyndin um „skóla án aðgreiningar“ skapað ójöfnuð. pessa pversögn parf málaflokkurinn að leysa með opinni upplýstri umræðu sem er laus við bæði fordóma og trúarbrögð.

Fyrir nemendur með lesblindu parf að próa viðeigandi úrræði og leiðir. Djónustan við pennan nemendahóp parf að taka mið af viðurkenndum greiningaraðferðum og pekkingu sem sækja má í sameiginlegan reynslubrunn velpjálfaðra kennara, sem fá nægilega marga nemendur með sömu eða sambærileg vandamál. Af pessum ástæðum m.a. verðskuldar saga Lestrarmiðstöðvarinnar, upphaf hennar, framvinda og endalok frekari rannsóknir svo draga megi lærdóm af pví sem par bæði vannst og tapaðist. 


\section{Aftanmálsgreinar}

1 Dessi rannsókn er birt í heild sinni í meistararitgerð sem ber yfirskriftina „Sundurleit stefna, Rannsókn á stefnu stjórnvalda gagnvart nemendum með lesblindu í grunnskóla,“ 2012 og má finna á skemman.is. Höfundur hennar er Nanna Björk Bjarnadóttir, félagsráðgjafi.

2 Lesblinda er pýðing á enska orðinu dyslexia sem er fræðiheiti nota yfir sérstaka tegund námserfiðleika (Elín Vilhelmsdóttir, 2007: Jónas G. Halldórsson, 2000). Hér er átt við erfiðleika sem er af líffræðilegum toga. Hann er meðfæddur og er talinn erfast (Høien og Lundberg, 2000). Ekki er vitað með vissu hvað veldur lesblindu og pess vegna ríkir ekki sátt meðal fræðimanna um skilgreiningu og nálganir. Flestir fræðimenn eru pó sammála um að orsök lesblindu sé af taugafræðilegum toga sem eigi rætur að rekja til starfsemi heilans og hún komi fram óháð greind (sjá t.d. Jónas G. Halldórsson, 2000: Reid, 2009: Rósa Eggertsdóttir og Póra Björk Jónsdóttir, 2006).

3 Um er að ræða doktorsrannsókn Sigurbjargar Sigurgeirsdóttur frá árinu 2005 sem ber yfirskriftina Health Policy and Hospital Mergers: How the impossible became possible. Gefin út af Háskólaútgáfunni î Reykjavík árið 2006 og á vefsíðu London School of Economics: http://www2.lse.ac.uk/home. aspx.

4 Slíka umfjöllun er hægt að finna í rannsókn Nönnu Bjarkar Bjarnadóttur frá árinu 2007 sem beindist að reynslu og viðhorfum foreldra sem eiga lesblint skólabarn og aðkomu skólafélagsráðgjafa. Einnig má benda á rannsókn sama höfundar á stefnu stjórnvalda gagnvart nemendum með lesblindu í grunnskóla frá árinu 2012, ásamt „Skýrslu nefndar um lestrarörðugleika og leshömlun“ sem var skipuð af menntamálaráðuneytinu árið 2007 og skýrslu Menntasviðs Reykjavíkurborgar um bætta pjónustu við nemendur með sértæka lestrarerfiðleika, frá árinu 2008. Ekki liggur fyrir rannsókn sem sýnir fjölda peirra foreldra sem leita úrræða utan skólakerfisins, hvers konar pjónustu peir eru að leita eftir og í hve miklum mæli. Đó er ljóst að ýmis úrræði og pjónusta er í boði fyrir lesblinda á almennum markaði sem bæði foreldrar og skólar sækjast eftir.

5 Dar sem fræðimenn nota ólíkar skilgreiningar og greiningartæki er nokkuð á reiki hversu margir nemendur í skólakerfinu eru taldir vera með lesblindu. Rannsóknir, sem hafa verið gerðar, gefa til kynna að um sé að ræða allt að 10\% af heildarfjölda nemenda (Sjá t.d. Menntasvið Reykjavíkurborgar, 2008: Rannveig G. Lund og Ásta Lárusdóttir, 2004: Rósa Eggertsdóttir, 1998). Talið er að petta sé stærsti hópur peirra nemenda sem glíma við námserfiðleika innan skólakerfisins (Menntamálaráðuneytið, 2007).

6 Hugtakið „,snemmtæk íhlutun“ er notað sem pýðing á enska orðasambandinu ,early intervention“ sem vísar til mikilvægi pess að hefja íhlutun snemma í lífi barns. Hægt er að lesa nánar um hugmyndafræðina sem liggur að baki hugtakinu í greininni „Snemmtæk íhlutun: markmið og leiðir“ eftir Tryggva Sigurðsson frá árinu 2001. Catts og Kamhi (2012), Jónas G. Halldórsson (2000) og Torgesen (2002) hafa fjallað um mikilvægi snemmtækrar íhlutunar varðandi lesblinda nemendur.

7 Bein pýðing úr ensku: samloðun, en hér býtt sem samstaða í merkingunni ‘sampjöppun pekkingar'.

8 Orðið lesblinda er gjarnan notað sem pýðing á hugtakinu „dyslexía“ sem er fræðiheiti notað yfir sérstaka tegund námserfiðleika (Elín Vilhelmsdóttir, 2007: Jónas G. Halldórsson, 2000). Fjölmörg önnur orð hafa verið notuð á Íslandi um pessa námserfiðleika. Að undanskildu orðinu lesblinda, má nefna leshömlun og sértakir námserfiðleikar, ásamt orðunum sértak lesröskun, sértakir og sérstakir lestrarörơugleikar, almennir lestrarerfiðleikar, svo eitthvað sé nefnt. Đó að pessi heiti vísi að einhverju leyti til ólíkra orsaka, sem mögulega geta útskýrt lesblindu, er hér einnig að finna ólíkar nálganir og skilgreiningar fræðimanna (Grétar L. Marinósson, o.fl., 1997). Í pessari grein verður notast við orðið lesblinda.

9 Sjá frekari umfjöllun um aðferðafræðilega nálgun rannsóknarinnar í Nanna Björk Bjarnadóttir, 2012.

10 Frekari umfjöllun um nýskipun í ríkisrekstri er að finna til dæmis í Frederickson og Smith, 2003, Gunnar Helgi Kristinsson, 2007 og Ómar H. Kristmundsson, 2000. 
11 Salamanca-yfirlýsingin er alpjóðlegur sáttmáli varðandi markmið og áætlun um menntun barna með sérparfir. Um er að ræða hugmyndafræðilega yfirlýsingu sem felur í sér að skólar eigi að taka við öllum börnum, hvernig sem háttað sé atgervi peirra til líkama og sálar, án tillits til tilfinningalegs eða félagslegs ástands eða málproska (UNESCO, 1994). Pess má geta að núverandi stefna stjórnvalda um „skóla án aðgreiningar“ próaðist út frá Salamanca-yfirlýsingunni (Mennta- og menningarmálaráðuneytið, 2011).

12 Reglugerð um nemendur með sérparfir í grunnskóla nr. 585/2010 og reglugerð um sérfræðipjónustu sveitarfélaga við leik- og grunnskóla og nemendaverndarráð í grunnskólum nr. 584/2010.

13 Menntamálaráðherra í ráouneyti Steingríms Hermannssonar frá september 1989 til apríl 1991 var Svavar Gestsson frá Alpýðubandalaginu, en eftir pað tók við samfelld ráðherratíð ráðherra menntamála úr röðum sjálfstæðismanna, allt frá apríl 1991 til janúar 2009. Pá var fjármálaráðuneytið î höndum Sjálfstæðisflokks samfleytt frá apríl 1991 til janúar 2009. Ráðherra heilbrigðismála í ráðuneyti Davíðs Oddssonar frá 1991 til 1995 var Sighvatur Björgvinsson en upp frá pví var heilbrigðisráðuneytið alfarið í höndum ráðherra Framsóknarflokksins frá 1995 til 2007.

\section{Heimildir}

Anna Guðmundsdóttir, Guðmundur S. Johnsen og Hermundur Sigmundsson (2007, 11. ma1). „Lesblinda - dyslexía - leshömlun“. Morgunbladid. Sótt 19. apríl 2013 af http://www.mbl.is/greinasafn/ grein/1144560/.

Baldur Pórhallsson (2010). „The corporatist model and its value in understanding small European states in the neo-liberal world of the twenty-first century: the case of Iceland“. European Political Science, 9, 375-386.

Barrett, S. og Fudge, C. (Ritstj.). (1981). Policy and Action: essays on the implementation of public policy. London: Methuen.

Birkland, T. A. (2005). An Introduction to the Policy Process: Theories, Concepts, and Models of Public Policy Making. Armonk, NY: M.E. Sharpe.

Björn Bjarnason (2000). „Málping um lesskimun - setningarraða. 6. júní 2000 “. Sótt pann 5. janúar 2012 af http://www.bjorn.is/greinar/nr/10.

Catts, H. M. \& Khami, A. G. (2012). Language and Reading Disabilities (3. útg.). Boston: Pearson.

Elín Vilhelmsdóttir (2007). Lesblinda: Dyslexia - fródleikur og ráogöö. Reykjavík: Félag lesblindra á Íslandi.

Frederickson, H. G. \& Smith, K. B. (2003). The Public Administration Theory Primer. Boulder, Colorado: Westview Press.

Grétar L. Marinósson, Fjölnir Ásbjörnsson, Jónas G. Halldórsson og Póra Kristinsdóttir (1997). Sértcke lesröskun: skýrsla starfshóps menntamálaráduneytisins um nemendur med sértaka lestrar- og réttritunarerfidleika i grunnskólum og frambaldsskólum. Reykjavík: Menntamálaráðuneytið.

Guðmundur Engilbertsson \& Rósa Eggertsdóttir (2004). Lesskimunarprófið Lasi. Skýrsla unnin fyrir Menntamálaráduneytið. Akureyri: Skólapróunarsvið Háskóla Akureyrar.

Gunnar Helgi Kristinsson (2007). Íslenska stjórnkerfið. Reykjavík: Háskóli Íslands.

Gunnar Helgi Kristinsson, Halldór Jónsson og Hulda Sveinsdóttir (1992). Atvinnustefna á Íslandi 1959 1991. Reykjavík: Félagsvísindastofnun Háskóla Íslands.

Gunnar Hersveinn. (2002, 31. maî). „Lokunin alvarleg mistök“. Morgunbladið. Sótt 3. ágúst 2012 af http://www.mbl.is/greinasafn/grein/670955/.

Hacker, J. S. (2002). Reform Without Change, Change Without Reform: The Politics of U.S. Health Policy in CrossNational Perspective. Paper prepared for Comparative Politics and Policymaking at the New Century. Presented at the Gordon Public Policy Centre: Brandeis University, Nóvember 2002.

Hagstofa Íslands (e.d.). Sveitarfélög. Sótt 17. april 2013 af http:/ /www.hagstofa.is/Hagtolur/Mannfjoldi/ Sveitarfelog.

Halldór Jónsson (1990). „Ákvarðanataka í sjávarútvegi og stjórnun fiskveiða“. Samfélagstídindi, 10, 99-142. 


\section{STJÓRNSÝSLA}

Helga Sigurjónsdóttir (1992). Skóli i kreppu. Greinar um menntun og skóla. Kópavogur: Náms- og foreldraráogjöf.

Helgi Jónasson (1996). Um sérkennslu og sérfræðipjónustu skóla. Í Rádstefna menntamálaráduneytisins um ýmis málefni barna og unglinga með sérparfir (bls. 49-53). Reykjavík: Menntamálaráðuneytið.

Héðinn Unnsteinsson og Pétur Berg Matthíasson (2012). „Stefnumótun og áætlunargerð ráðuneyta. Leiðir að einföldun og samhæfingu“. Stjórnmál og stjórnsýsla, 8(1), 153-172. Sótt 27. júní 2012 af http://skemman.is/stream/get/1946/12294/30683/1/a.2012.8.1.7.pdf.

Hill, M. (2009). The Public Policy Process (5. útgáfa). Harlow, England: Longman.

Hirschman, A. O. (1969). Exit, Voice and Loyalty. Cambridge, Massachusetts: Harvard University Press.

Howlett, M. og Ramesh, M. (2003). Studying Public Policy. Policy Cycles and Policy Subsystems (2. útgáfa), Canada: Oxford University Press.

Høien, T. \& Lundberg, I. (2000). Dysleksi. Fra teori til praksis (2. útg.), Oslo: Gyldendal Akademisk.

Jónas G. Halldórsson (2000). „Sértæk lesröskun“. Glaður, 10(2), 27-34.

Kavanagh, D., Richard, D., Smith, M. og Geddes, A. (2006). British Politics (5. útgáfa), New York: Oxford University Press.

Kettle, D. F., 1993. Sharing Power: public governance and private markets. Washington D.C.: Brookings Institution.

Kingdon, J. W. (2003). Agendas, Alternatives, and Public Policies (2. útgáfa), New York: Longman.

Kristín Elva Guðnadóttir (2003). „Aftur til fortíðar í bjónustu við nemendur með dyslexíu?“ Skólavarðan. Málgagn Kennarasambands Íslands, 3(3), 12-18.

„Lestrarmiðstöð annar ekki eftirspurn“ (1999, 21. apríl). Morgunbladið. Sótt 10. ágúst 2012 af http:// www.mbl.is/greinasafn/grein/462998/?item_num=92\&dags=1999-04-21.

„Lestrarerfiðleikar furðu algengir“ (2000, 4. júnî). Morgunbladið. Sótt 10. ágúst 2012 af http://www.mbl. is/greinasafn/grein/539153/?item_num $=18 \&$ dags $=2000-06-04$.

Lindbloom, C. E. (1959). „The Science of Muddling Through“. Public Administration Review, 19, 79-88.

Lindblom, C. E. (1979). „Still Muddling, not yet through“. Public Administration Review 39(6): 517-526.

Lög um grunnskóla nr. 91/2008.

Menntamálaráđuneytið (1990). Til nýrrar aldar. Drög a framkvamdaáatlun menntamálaráduneytisins i skólamálum til ársins 2000. Reykjavík: Menntamálaráduneytið.

Menntamálaráðuneytið (1991). Lestrarördugleikar i nútímasamfélagi. Erindi flutt á rádstefnu sem var haldin i tilefni af Ári lasis 27. október 1990. Reykjavík: Menntamálaráðuneytið.

Menntamálaráđuneytið (1998). Enn betri skóli. Deirra réttur - okkear skylda. Grundvöllur endurskodunar aðalnámskráa. Reykjavík: Menntamálaráðuneytið.

Menntamálaráđuneytið (1999). Aðalnámskrá grunnskóla 1999. Almennur bluti. Reykjavík: Menntamálaráðuneytið.

Menntamálaráðuneytið (2007). Skýrsla nefndar um lestrarörðugleika og leshömlun. Reykjavík: Menntamálaráðuneytið. Sótt 13. september 2012 af http://brunnur.stjr.is/mrn/utgafuskra/utgafa.nsf/RSSPage. xsp?documentId=02BA5864704A0D69002576F00058DC4C\&action=openDocument.

Mennta- og menningarmálaráðuneytið (1994). Nefnd um mótun menntastefnu: Skérrsla. Sótt 13. ágúst 2012 af http://www.menntamalaraduneyti.is/utgefid-efni/utgefin-rit-og-skyrslur/HTMLrit/nr/2091.

Mennta- og menningarmálaráðuneytið (2000). Lestrarörougleikar og lesskimun-06.06.2000. Sótt 20. april 2013 af http://www.menntamalaraduneyti.is/verkefni/malthing_og_radstefnur/2000/05/23/ $\mathrm{nr} / 982$.

Mennta- og menningarmálaráðuneytið (2011). Aðalnámskrá grunnskóla. Almennur bluti. Reykjavík: Mennta- og menningarmálaráðuneytið.

Menntasvið Reykjavíkurborgar (2008). Skýrsla framkvamdahóps um batta pjónustu við nemendur meঠ sértaka lestrarerfiðleika. Reykjavík: Menntasvið Reykjavíkurborgar. Sótt 26. maí 2013 af http://www.reykjavik.is/Portaldata/1/Resources/Skola_og_fristundasvid/skyrslur/Skyrsla_starfshopslesroskun_08. pdf. 
Mintzberg, H. (1993). Structure in Fives: Designing Effective Organizations (2. útgáfa), Englewood Cliffs, New Jersey: Prentice Hall Inc.

Nanna Björk Bjarnadóttir (2007). Detta er náttúrlega eitthvað sem parf að bata: athugun á reynslu og viðhorfum foreldra sem eiga lesblint skólabarn og aðkomu skólafélagsrádgjafa. Óbirt BA-ritgerð: Háskóli Íslands.

Nanna Björk Bjarnadóttir (2012). Sundurleit stefna. Rannsókn á stefnu stjórnvalda gagnvart nemendum med lesblindu i grunnskóla. Óbirt MPA-ritgerð: Háskóli Íslands.

Ómar H. Kristmundsson (2000). Reinventing government in Iceland: a case study of public management reform. Reykjavík: University of Iceland Press.

Pettigrew, A. M. (1997). „What is a processual analysis?“". Scandinavian journal of Management, 13(4), 337-348.

Pressman, J. L. og Wildavsky, A. B. (1973). Implementation : how great expectations in Washington are dashed in Oakland: or, Why it's amazing that Federal programs work at all, this being a saga of the Economic Development Administration as told by two sympathetic observers who seek to build morals on a foundation of ruined hopes. Berkeley: University of California Press.

Rannveig Lund (1993). „Lestrarráðgjöf Lestrarmiðstöðvar KHÍ“. Glađur. Fagtímarit félags islenskera sérkennara, 3, 10-12.

Rannveig Lund \& Ásta Lárusdóttir. (2004). GRP 14b-Handbók. Greinandi ritmálspróf fyrir 14 ára nemendur. Reykjavík: Höfundar.

Reglugerð um sérfrađïjónustu skóla nr. 386/1996 með áorðnum breytingum 905/2003.

Reglugerd um nemendur mè sérparfir í grunnskóla nr. 585/2010.

Reglugerd um sérfrađitjónustu sveitarfélaga vid leik- og grunnskóla og nemendaverndarrád i grunnskólum nr. $584 / 2010$.

Reid, G. (2009). Dyslexia. A Practitioner's Handbook (4. útgáfa). Chichester: Wiley-Blackwell.

Rhodes, R. A. W. (1999). Understanding Governance. Policy Networks, Governance, Reflexivity and Accountability (2. útgáfa), Buckingham: Open University Press.

Ríkisendurskoðun (2011). Útvistun verkefna til Bandasamtaka Íslands. Skérsla til Alpingis. Sótt 15. april 2013 af http://www.rikisend.is/skyrslur-radad-eftir-malaflokkum/atvinnuvega-og-samgongumal.html.

Rósa Eggertsdóttir (ritstj.) (1998). Fluglasi: Áherslur, stefnumörkun og adferdir i lestrarkennslu. Akureyri: Skólapjónusta Eypings.

Rósa Eggertsdóttir \& Dóra Björk Jónsdóttir (2006). Lexía. Frađi um leshömlun, kenningar og mat. Reykjavík: Háskólaútgáfan.

Sigurbjörg Sigurgeirsdóttir (2006a). Health Policy and Hospital Mergers. How the Impossible became Possible. London: London School of Economics and Political Science. Háskólaútgáfan í Reykjavík.

Sigurbjörg Sigurgeirsdóttir (2006b). Frá starfi til stefnu: Er stefna í heilbrigðismálum afrakstur af faglegri stefnumörkun eða pólitískri stefnumótun? Í Sigrún Júlíusdóttir og Halldór Sig. Guðmundsson (Ritsti.). Heilbrigði og heildarsýn: félagsrádgöö í heilbrigðispjónustu (bls. 62-77). Reykjavík: Rannsóknasetur í barna- og fjölskylduvernd.

Sigurbjörg Sigurgeirsdóttir (2006c). „Straumar, stjórnleysi og stefnurek. Hvað er til ráða?“ Stjórnmál og stjórnsýsla 2(1), 1-18. Sótt 11. nóvember 2011 af http://skemman.is/handle/1946/8928.

Simon, H. (1947). Administrative Behavior. New York: The Free Press.

Svanur Kristjánsson (2011). „Varð pjóðpingið að pjófpingi? :Lýðræðið og kvótakerfið 1983“. Skirnir, 185, 261-291.

Torgesen, J. K. (2002). „The prevention of reading difficulty“. Journal of School Psychology 40(1), 1-26.

Tryggvi Sigurðsson (2001). „Snemmtæk íhlutun: markmið og leiðir“. Glaður 11(1), 39-44.

Tuohy, C. H. (1999). Accidental Logics: The Dynamics of Change in the Health Care Arena in the United States, Britain, and Canada. New York: Oxford University Press.

UNESCO (1994). The Salamanca statement and framework. for action on special needs education. World conference on special needs education: access and quality, Salamanca, Spain 7.-10. jüní. París: UNESCO.

porgerður Katrín Gunnarsdóttir (2006). „Stefna i málefnum lesblindra nemenda“. Sótt 10. ágúst 2012 af http://www.mbl.is/greinasafn/grein/1108522/. 